\title{
I
}

\author{
Institute of Natural Resource Sustainability
}

\section{Nesting Biology of Mallards in West-central Illinois}

Aaron P. Yetter, Joshua D. Stafford, Christopher S. Hine, Matthew W. Bowyer, Stephen P. Havera, and Michelle M. Horath 


\section{I L L L I N O I I S}

Institute of Natural Resource Sustainability

William Shilts, Executive Director

Illinois Natural History Survey

Brian D. Anderson, Director

Forbes Natural History Building

1816 South Oak Street

Champaign, Illinois 61820

217-333-6880

Citation:

Yetter, A.P., J.D. Stafford, C.S. Hine, M.W. Bowyer, S.P. Havera, and M.M. Horath. 2009. Nesting biology of Mallards in west-central Illinois. Illinois Natural History Survey Bulletin 39(1):1-38.

Science editor: Jeff Levengood

Production editor: Charles Warwick

US ISSN 0073-4918

US ISBN 1-882932-22-6

Printed by authority of the University of Illinois

(C) 2009

$\mathrm{P} 0276370-.45 \mathrm{M}-09-09$

Printed with soy ink on recycled and recyclable paper.

The University of Illinois will not engage in discrimination or harassment against any person because of race, color, religion, national origin, ancestry, age, marital status, disability, sexual orientation including gender identity, unfavorable discharge from the military or status as a protected veteran and will comply with all federal and state nondiscrimination, equal opportunity and affirmative action laws, orders and regulations. This nondiscrimination policy applies to admissions, employment, access to and treatment in University programs and activities.

University complaint and grievance procedures provide employees and students with the means for the resolution of complaints that allege a violation of this Statement. Inquiries or complaints may be addressed to the Director and Assistant Chancellor, Office of Equal Opportunity and Access, 601 East John Street, Swanlund Administration Building, (217) 333-0885, fax (217) 244-9136, TTY (217) 244-9850 or the Associate Provost and Director, Academic Human Resources, Henry Administration Building, (217) 333-6747, fax (217) 244-5584. For other University of Illinois information, contact University Directory Assistance at 333-1000. 


\title{
Nesting Biology of Mallards in West-central Illinois
}

\author{
Aaron P. Yetter ${ }^{1}$, Joshua D. Stafford ${ }^{1}$, \\ Christopher S. Hine ${ }^{1}$, \\ Matthew W. Bowyer ${ }^{2}$, Stephen P. Havera ${ }^{1}$, and \\ Michelle M. Horath ${ }^{1}$
}

\author{
1. Illinois Natural History Survey \\ Frank C. Bellrose Waterfowl Research Center and \\ Forbes Biological Station \\ 20003 CR 1770 E \\ PO Box 590 \\ Havana, IL 62644 \\ 2. Missouri Department of Conservation \\ 2206 W. St. Joseph \\ Perryville, MO 63775
}

Correspondence to:

Aaron P. Yetter

Frank C. Bellrose Waterfowl Research Center

and Forbes Biological Station

20003 CR $1770 \mathrm{E}$

PO Box 590

Havana, IL 62644

309-543-3950

ayetter@inhs.illinois.edu 


\section{CONTENTS}

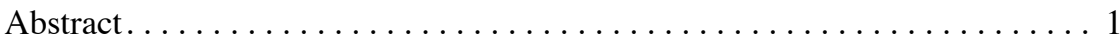

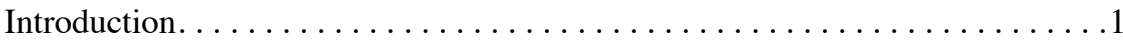

Study Area. . . . . . . . . . . . . . . . . . . . . . .

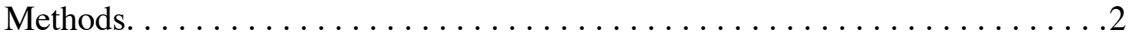

Trapping and Transmitter Attachment $\ldots \ldots \ldots \ldots \ldots \ldots \ldots \ldots \ldots . \ldots \ldots$

Radio Telemetry and Nest Monitoring $\ldots \ldots \ldots \ldots \ldots \ldots \ldots \ldots \ldots$

Nesting Habitat . . . . . . . . . . . . . . . . . . . . . . . 5

Recruitment. ...........................

Statistical Analyses . . . . . . . . . . . . . . . . . . . . . 5

Nesting Parameters and Body Condition $\ldots \ldots \ldots \ldots \ldots \ldots \ldots \ldots$

Hen, Brood, and Duckling Survival . . . . . . . . . . . . . . 6

Results. . . . . . . . . . . . . . . . . . . . . . . . . . . 7

Morphological Measurements and Body Condition Indices . . . . . . . . .7

Nesting Parameters . . . . . . . . . . . . . . . . . . . . . . .

Brood Size . . . . . . . . . . . . . . . . . . . . . . . . . 14

Survival .................................

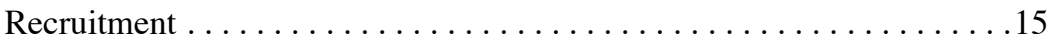

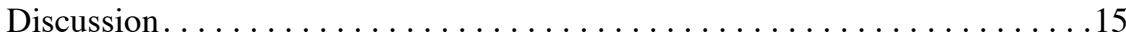

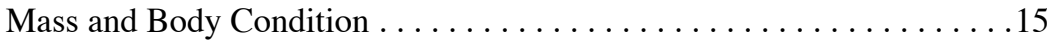

Nest Initiation. . . . . . . . . . . . . . . . . . . . . . 15

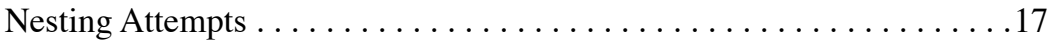

Clutch Size. . . . . . . . . . . . . . . . . . . . . . . . . 18

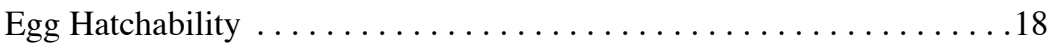

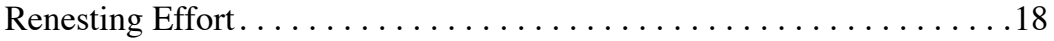

Nest Success. . . . . . . . . . . . . . . . . . . . . . . 19

Nesting Habitat Use. . . . . . . . . . . . . . . . . . . . . . . . . . . 19

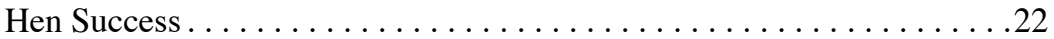

Brood Size . . . . . . . . . . . . . . . . . . . . . . . . . 22

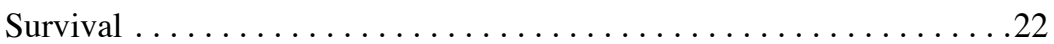

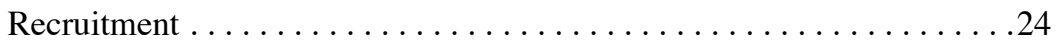

Conclusions and Management Implications $\ldots \ldots \ldots \ldots \ldots \ldots \ldots \ldots \ldots$

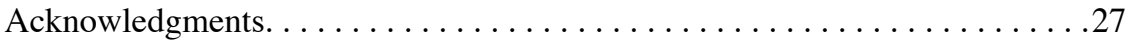

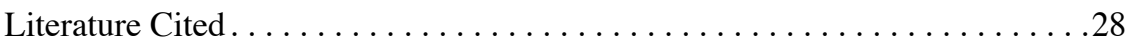




\section{ABSTRACT}

The number of Mallards (Anas platyrhynchos) breeding in Illinois and eastern North America has increased in recent decades; however, few studies have investigated the nesting biology of Mallards outside primary production areas. Therefore, we radiomarked resident female Mallards $(n=$ 148) in west-central Illinois during 1998-2003 to assess nesting parameters and evaluate recruitment.

Mean initiation date for first nests ranged from 22 April to 6 May, and the majority (75\%) of nests were initiated by 20 May. Therefore, the majority of nests were predicted to hatch by 24 June. The nesting season averaged 88 days (range: $77-103$ days). The proportion of unsuccessful females that renested ranged from $50.0-85.7 \%$, and adults were more likely to renest $(75.0 \%)$ than yearlings (48.0\%). Nest success ranged from $9.8-33.3 \%$ and was $19.6 \%$ overall; hen success was $28.3 \%$.

Initial brood size was $8.2 \pm 0.3$ ducklings, but brood size declined to $3.0 \pm 0.6$ ducklings by 17 days posthatch. Brood survival to 20 days was $0.759 \pm 0.081$, and 20 -day duckling survival was $0.413 \pm 0.035$. Female survival during spring-summer ranged from $0.546-1.00$ and averaged $0.710 \pm 0.096$. Likewise, estimated Mallard recruitment varied annually (range: $0.302-0.672$ female ducklings/female). Assuming constant female and duckling survival, we estimated that a recruitment rate of 0.613 female ducklings/adult female was necessary to maintain a stable Mallard breeding population in west-central Illinois.

Estimated Mallard reproduction and recruitment was similar to that observed in other areas of North America. Nest success and hen success approached or exceeded estimated thresholds for population stability in most years; however, hen success averaged over the study period was insufficient for local population maintenance and growth. Female survival was comparable to that observed in other studies but may have limited population growth in some years. Duckling survival was sufficient for population maintenance. Management designed to enhance hen success and brood habitat may augment Mallard recruitment in west-central Illinois.

\section{INTRODUCTION}

The Mallard (Anas platyrhynchos) is the most abundant duck in North America; thus, it is socially, economically, and ecologically important (USFWS 2007a). Further, the Mallard is the most frequently harvested duck in Illinois, the Mississippi Flyway, and the United States (USFWS 2007b). Consequently, Mallards have been the focus of intense scientific investigation in North America. Most previous studies of Mallard breeding ecology have been conducted in the north-central United States and central Canada (i.e., the Prairie Pothole and Parkland regions) with little attention given other areas. However, recent studies have investigated breeding ground demographic rates in California, the Great Lakes Region, and eastern North America (Simpson et al. 2005, Hoekman et al. 2006a, 2006b, Chouinard and Arnold 2007, Coluccy et al. 2008, Davis 2008).
Mallard breeding populations outside of the Prairie Pothole Region have expanded in recent years. In the late 1980s, an estimated 225,000 Mallards bred annually in Wisconsin, Michigan, and Ohio (Petrie 1999); this estimate increased to 503,000 in 2007 for Wisconsin and Michigan alone (USFWS 2007a). Wetlands in nontraditional nesting areas, such as the Great Lakes Region, are less susceptible to drought than prairie wetlands (Simpson et al. 2005), resulting in more stable nesting and broodrearing conditions that may have contributed to this increase.

Breeding Mallards were not abundant in Illinois during the early 1900s, although they may have been common in the glaciated pothole region of northeastern Illinois (i.e., Boone, Cook, DeKalb, DuPage, Kane, Lake, McHenry, Will, and Winnebago counties [Havera 1999]). Ford et al. (1934) classified Mallards as permanent residents of the urbanized Chicago region. 
Prior to this, Kennicott (1855) observed that nesting Mallards were abundant in Cook County, and Nelson (1876:138) reported that Mallards commonly nested in Lake and Cook counties. Research conducted in 1942 in northeastern Illinois documented low densities of Mallard nests (1.1 nest $/ \mathrm{km}^{2}$; [J.B. Low, Illinois Natural History Survey (INHS), unpublished data]), but by 1956 Mallards were nesting in "substantial numbers" in northeastern Illinois (S.H. Garland, INHS, unpublished data). Havera (1999:105-106) identified 15 records of nesting Mallards in 9 northern Illinois counties prior to 1930, but by 1990 Mallards were reported to nest in every county in Illinois. Emphasizing this increase, Yetter (1992) observed 3.4 breeding pairs $/ \mathrm{km}^{2}$ in northeastern Illinois during the early 1990s. The North American Breeding Bird Survey (BBS) indicated Mallards increased 214\% in Illinois from 1966 to 1989 (Droege and Sauer 1990, Havera 1999), although recent data from the BBS indicated that Mallard population growth was leveling off (Sauer et al. 2007).

Due to their expanded range, Mallards produced in the Great Lakes states (including Illinois) comprise an increasing proportion of the Mallard harvest in Illinois. For example, 9\% of Mallards harvested in Illinois were produced in the Great Lakes states during 1961-1975, whereas $28 \%$ of the harvest originated from this region in the 1990s (Zuwerink 2001). Clearly, this increased harvest emphasizes the importance of the Great Lakes Region to Illinois and mid-continent Mallard populations. However, little information existed regarding the productivity of Mallards along the Illinois River corridor, an important ecoregion to waterfowl. Therefore, we initiated this study to 1 ) determine nesting effort and success; 2) assess brood, duckling, and female survival; and 3) estimate recruitment of Mallards breeding in west-central Illinois.

\section{STUDY AREA}

We selected study areas based upon accessibility and perceived resident Mallard densities. These included Banner Marsh State Fish and
Wildlife Area (Banner) and the Prairie Plan site of the Metropolitan Water Reclamation District of Greater Chicago (MWRD) (Fig. 1). Banner was located in the Illinois River floodplain in Fulton and Peoria counties. This site was leveed from the Illinois River for agriculture and subsequently surface-mined for coal before its acquisition by the state of Illinois in the 1980s. It was managed by the Illinois Department of Natural Resources (IDNR) for outdoor recreation and fish and wildlife habitat and consisted of 1,766 ha of wetlands and deepwater habitats, upland forests, idle grasslands, cattle pastures, hayfields, old fields, and row crops (Photo 1). Upland nesting cover at Banner included smooth brome (Bromus inermis), switch grass (Panicum virgatum), fescue (Festuca sp.), forbs (e.g., goldenrod [Solidago spp.]), autumn olive (Elaeagnus umbellata), multiflora rose (Rosa multiflora), and willows (Salix spp.). We did not conduct research at Banner after 1998 because of our inability to capture an adequate sample of females at this site.

Prairie Plan was located in Fulton County and consisted of 6,284 ha of reclaimed surfacemined lands (Photo 2; Patterson 1982). This area was managed as a disposal site for biosolids that were spread over agricultural fields and incorporated into the soil. Major land categories at MWRD included idle grasslands, hayfields, cattle pastures, row crop and small grain agriculture, upland forests, and a variety of wetland and deepwater habitats ranging from large lakes created by strip-mining for coal to small ponds and marshes. Upland nesting cover at MWRD was dominated by smooth brome, meadow fescue, orchard grass (Dactylis glomerata), timothy (Phleum pratense), alfalfa (Medicago sativa), red clover (Trifolium pratense), goldenrod, multiflora rose, autumn olive, and willows.

\section{METHODS}

\section{Trapping and Transmitter Attachment}

We used decoy traps to capture Mallards prior to nesting during the period 1998 to 2003 (Photo 3; Sharp and Lokemoen 1987, Ringelman 1990). We did not detect an age-related bias in 


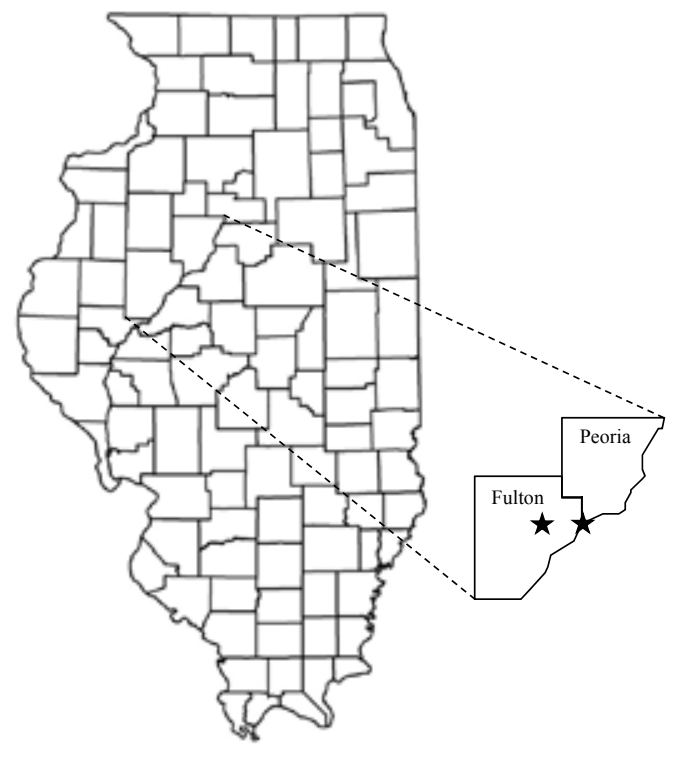

Figure 1. Location of study areas for Mallard (Anas platyrhynchos) nesting biology investigations in west-central Illinois, 1998-2003.

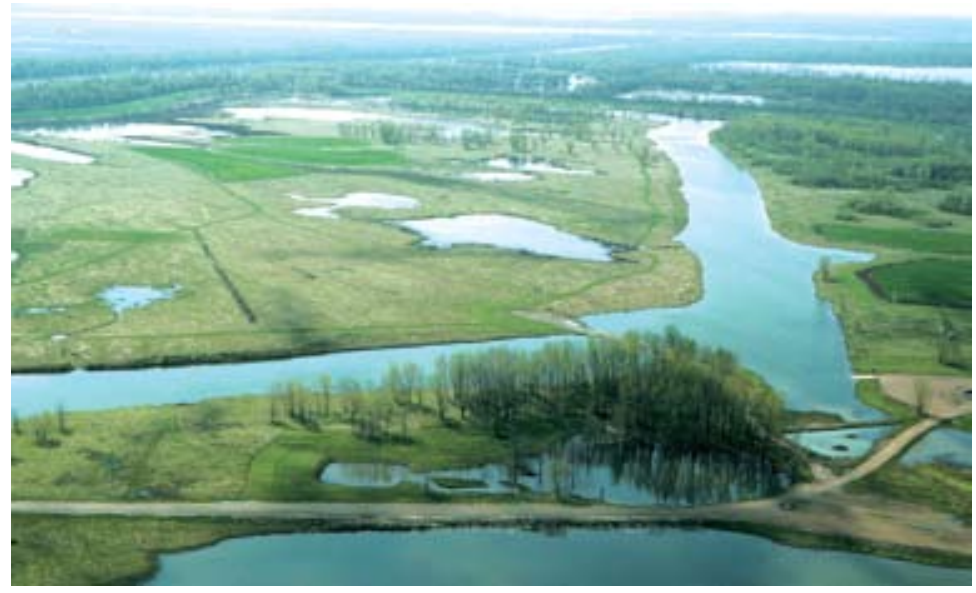

Photo 1. Aerial photo of the Banner Marsh State Fish and Wildlife Area (Banner) in Fulton and Peoria counties, Illinois, April 1998. Photo by Michelle M. Horath.

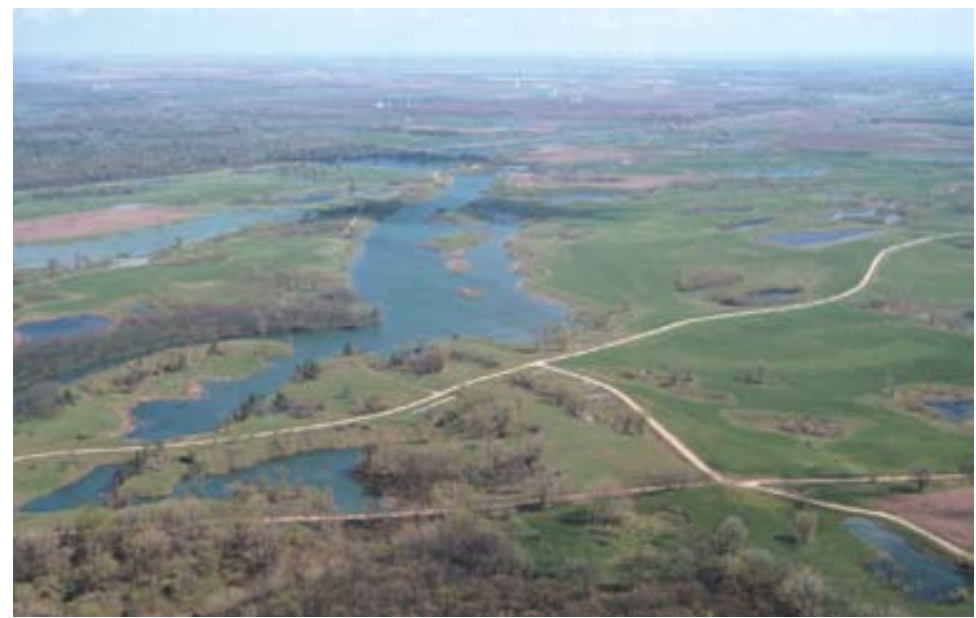

Photo 2. Aerial photo of the Prairie Plan site of the Metropolitan Water Reclamation District of Greater Chicago (MWRD) in Fulton County, Illinois, April 1998. Photo by Michelle M. Horath. 
the trapability of female Mallards. We began trapping in mid-March, after the peak of spring migration (Havera 1999). We weighed ( $\pm 10 \mathrm{~g})$ and banded individuals with USFWS size 7A leg bands. Additionally, we recorded culmen length, bill width, tarsus length, and tarsus width $( \pm 0.1 \mathrm{~mm}$; Byers and Cary 1991), and wing chord length ( $\pm 1 \mathrm{~mm}$; Carney 1992, Hine et al. 1996). We aged females as yearling (first breeding season) or adult ( $\geq$ second breeding season) following Krapu et al. (1979a). We radiomarked females using prong and suture radio transmitters (Photo 4; Mauser and Jarvis 1991, Pietz et al. 1995) equipped with 120-day batteries and 12-hr mortality switches. Transmitters weighed about $1 \%(12-13 \mathrm{~g})$ of a female's body mass at capture and were attached under local anesthetic (lidocaine). Handling time was $<30 \mathrm{~min}$, and we released females immediately after transmitter attachment. Capture, handling, and transmitter-attachment procedures were approved by the University of Illinois Institutional Animal Care and Use Committee (Protocol \# 03012).

\section{Radio Telemetry and Nest Monitoring}

We considered females to be residents if they attempted to nest or remained on the study area during the nesting season. We located radiomarked females by triangulation twice daily ( $\geq$ 6 days/week) between 0600 and 1300 hrs using vehicle-mounted, null-

array antenna systems and hand-held antennas and recorded daily locations on aerial photographs (White and Garrott 1990, Gloutney et al. 1993, Samuel and Fuller 1996). Females located in nesting cover for $\geq 2$ consecutive locations were approached on foot with a hand-held antenna in an attempt to locate nests by triangulation without flushing the female (Paquette et al. 1997). We searched for nests while females were away from the nest site and verified nest fate (i.e., active, abandoned, destroyed, or hatched) if a female was located off her nest for $\geq 2$ consecutive telemetry locations (Klett et al. 1986, Paquette et al. 1997). We conservatively evaluated evidence from destroyed nest sites to identify nest predators (Smith 1982, Sovada et al. 1996, Hernandez et al. 1997, Sargeant et al. 1998). For nests located during laying we determined initiation date by backdating the number of eggs present from the date of nest discovery (assuming a laying interval of one egg per day and partial nest predation had not occurred). Otherwise, we assessed nest initiation date by candling eggs (Weller 1956) and subtracting the estimated incubation stage and number of eggs present from the day the nest was found (Klett et al. 1986, Paquette et al. 1997). When we failed to locate a nest prior to depredation, we estimated nest initiation from the female's daily movements or the first day she was located at the nest site.

We visited nests on the estimated 18th day of incubation to determine the incubated clutch size, assuming partial nest predation had not occurred. We determined egg hatchability from the presence of whole eggs and membranes at the nest site (Davis et al. 1998), defined a successful nest as hatching $\geq 1$ egg (Klett et al. 1986), and defined hen success as the probability of a female having a successful nest in

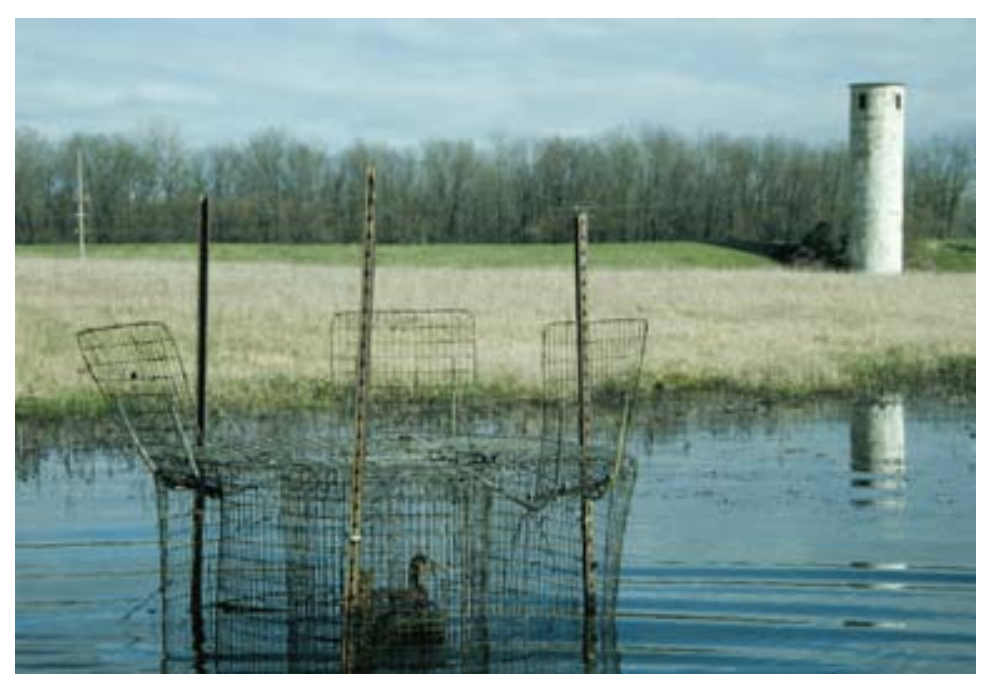

Photo 3. Decoy trap used to capture Mallards (Anas platyrhynchos) in westcentral Illinois, 1998-2003. Photo by Michelle M. Horath. 


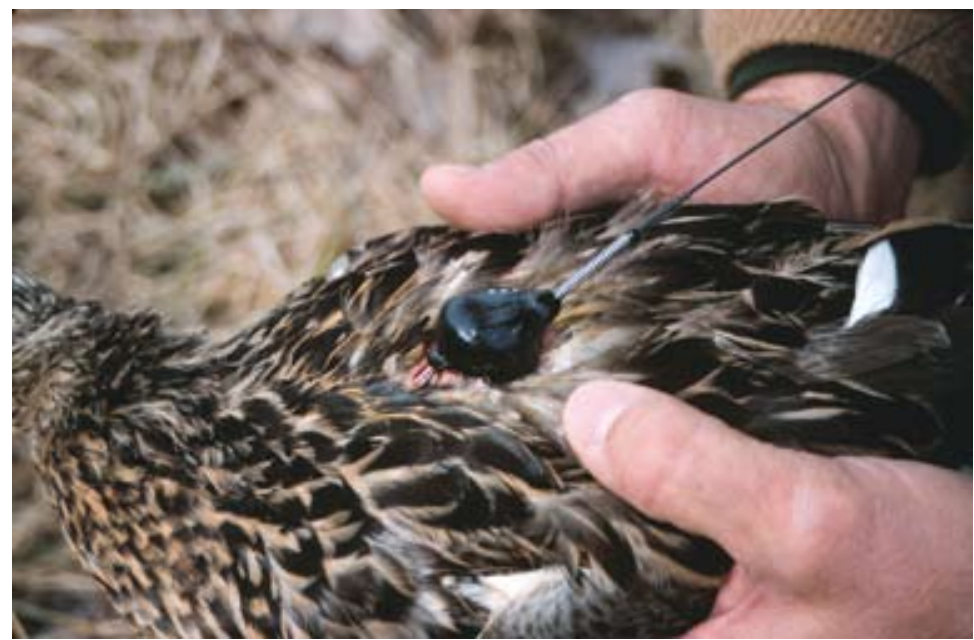

Photo 4. Prong and suture radio transmitter used to investigate the productivity of female Mallards (Anas platyrhynchos) in west-central Illinois, 1998-2003. Photo by Paul F. White.

one or more nest attempts (Cowardin et al. 1985, Klett et al. 1986). We located females with broods daily until 20 days posthatch, and we attempted to count ducklings multiple times each week from distant vantage points to ascertain brood and duckling survival. Brood females were flushed daily in 1998 to verify brood size; however, we reduced brood monitoring intensity in subsequent years by flushing broods once per week.

\section{Nesting Habitat}

We estimated the composition of Mallard nesting habitats at MWRD by digitizing cover types within 12.57-ha random circular plots $(n=50$ each in 2001 and 2002). Habitat delineations were verified in the field and digitized on 1998 aerial imagery using ArcView GIS 3.3. We assumed the distribution of nesting habitats measured in 2001-2002 were representative of the study period because habitat composition within plots was similar between years.

\section{Recruitment}

We defined recruitment $(\mathrm{R})$ as the number of female ducklings surviving to 20 days posthatch per nesting female in spring. We estimated recruitment according to Mauser and Jarvis (1994) as: $\left(\mathrm{R}=\mathrm{HGS}_{\mathrm{d}} / 2\right)$, where $\mathrm{H}=$ hen success, $\mathrm{G}=$ mean brood size at hatch, and $\mathrm{S}_{\mathrm{d}}=$ duckling survival to 20 days posthatch. We monitored duck- ling survival to 20 days because most duckling mortality occurs within this period (Orthmeyer and Ball 1990, Mauser et al. 1994a). This method assumed a 50:50 sex ratio of ducklings, hence division by 2 in the equation. We estimated the proportional change in population size (C) each spring following Mauser and Jarvis (1994): $\mathrm{C}=\mathrm{S}\left(1+\mathrm{DR} / \mathrm{S}_{\mathrm{b}}\right)$, where $\mathrm{S}$ was the annual adult female survival $(0.520 \pm$ 0.029 ; Smith and Reynolds 1992:312), D was the ratio of annual yearling survival $(0.556 \pm 0.049$, Smith and Reynolds 1992:312) to adults, $R$ was our estimate of recruitment, and $\mathrm{S}_{\mathrm{b}}$ was our estimate of summer (i.e., breeding season) female survival (age classes combined).

\section{STATISTICAL ANALYSES}

\section{Nesting Parameters and Body Condition}

We defined nesting-season length as the interval (days) from the date the first egg was laid to the date the last nest hatched or was destroyed. We compared mean number of nest attempts per female, initiation dates for first nests, incubated clutch size, and female body condition indices (i.e., body mass [g]/ wing chord [mm]; Ringelman and Szymczak 1985, Hine et al. 1996) among years, between age classes, and their interaction using twoway analysis of variance (ANOVA). We used Tukey/Kramer means comparison tests when significant $(P \leq 0.05)$ main effects were detected (Proc GLM, SAS Institute, Inc., Cary, NC). Nonsignificant $(P>0.05)$ interactions were removed from models. We used simple linear regression to evaluate the relationship between nest initiation date and incubated clutch size (Proc REG, SAS Institute, Inc., Cary, NC), and we tested for annual differences in brood size at hatch and male body 
condition indices using one-way ANOVA and Tukey/Kramer post-hoc tests (SAS Institute, Inc., Cary, NC).

We modeled apparent nest success (Klett et al. 1986) and hen success using an informationtheoretic approach as a constant function (intercept only) and with respect to female age (AGE), year (YEAR), and nest initiation date (NESTINIT, nest success model only; Burnham and Anderson 2002, Dinsmore et al. 2002). We conducted modeling using the GLIMMIX procedure using METHOD=LAPLACE and specifying a binomial distribution and logit link function (SAS Institute, Inc., Cary, NC). Further, we accounted for dependence in success rates of females monitored for $>1$ year via the RANDOM statement. We determined best approximating and competing models by outputting second-order Akaike's Information Criterion (AIC ; Burnham and Anderson 2002) in PROC GLIMMIX and considered models within $2.0 \mathrm{AIC}_{c}$ units of the best approximating model competitive. We did not include a covariate in nest success models identifying habitat use at nest sites because this information did not exist for all monitored females. Therefore, we used G-tests to evaluate nest success with respect to habitat types in the immediate vicinity of the nest bowl (i.e., vegetative class at the nest bowl) for nests located at MWRD during 1998-2003 (Table 1). We presented renesting effort and egg hatchability as simple proportions and compared these among years and between age classes using G-tests; 2 x 2 comparisons employed a Yates correction for continuity (Zar 1996). We used $t$-tests to compare first nest initiation dates between renesting females and unsuccessful females with only 1 nest attempt. We considered differences significant at $\mathrm{P} \leq 0.05$, and report means $\pm 1 \mathrm{SE}$.

\section{Hen, Brood, and Duckling Survival}

We calculated female survival encompassing the prenesting, nesting, and brooding periods using the Kaplan-Meier product-limit estimator modified for staggered entry (Kaplan and Meier 1958, Pollock et al. 1989, White and Garrott 1990). For determining survival, we censored females either the day following last radio contact, the day following transmitter loss, the day of brood loss, or the 20th day posthatch (Paquette et al. 1997). We used the Cox proportional hazards model (Proc PHREG, SAS Institute, Inc., Cary, NC; Kleinbaum 1996) to test for differences in survival in relation to year and female age. We estimated brood and duckling survival rates using the Kaplan-Meier product-limit estimator (Proc LIFETEST, SAS

Table 1. Description of nesting habitats classified at the Prairie Plan site of the Metropolitan Water Reclamation District of Greater Chicago (MWRD) in west-central Illinois, 2001-2003.

Habitat type Description

Cropland

Idle grassland

Hay/idle mowed

Forested

Scrub

Pond
Row crop and small grain agriculture and stubble of previously cropped fields used for disposal of biosolids.

Grasslands or planted cover not mowed during the growing season.

Vegetation cut for hay or mowed periodically during summer and typically included roadsides and odd areas.

Woody vegetation $\geq 6 \mathrm{~m}$ tall.

Woody vegetation $<6 \mathrm{~m}$ tall.

Basins classified as palustrine habitats ( $\leq 2 \mathrm{~m}$ deep) by the National Wetlands Inventory (NWI) (Cowardin et al. 1979).

Nonwoody vegetation used for livestock grazing. 
Institute, Inc., Cary, NC), and used log-rank tests to compare brood survival between female age and among year classes (White and Garrott 1990:241). We censored 5 broods from brood survival estimates and 52 ducklings ( 6 broods) from duckling survival the second day posthatch due to transmitter and tracking failures. We pooled duckling survival across years 1998-2003 due to limited observations of ducklings.

\section{RESULTS}

We captured 148 resident female Mallards and 61 males paired with radiomarked females during 1998-2003 (Table 2). The median age ratio of females was 0.66 yearling:adult, though values varied considerably. Breeding incidence was high with only 6 of 143 females $(4.2 \%)$ not nesting. Five non-nesting females $(83.3 \%)$ were yearlings, and the resulting age distribution for nesting females was 0.61 yearling:adult.

\section{Morphological Measurements and Body Condition Indices}

Breeding season body mass of male Mallards averaged 1,193 g (range: $980-1,370 \mathrm{~g}$; Table 3 ). Mean body condition indices for males differed among years $\left(\mathrm{F}_{5,60}=3.14 ; P=0.015\right)$ and was $8 \%$ greater in 2000 than $1999(P \leq 0.05)$.
Female body mass differed among age classes $\left(\mathrm{F}_{1,147}=19.47 ; P<0.001\right)$, but not years $\left(\mathrm{F}_{5,147}=2.04 ; P=0.077\right)$, and mean body mass of adults exceeded yearlings by $6 \%$ (Table 4). However, female body condition differed among years $\left(\mathrm{F}_{5,147}=3.25 ; P=0.008\right)$ and age classes $\left(\mathrm{F}_{1,147}=8.70 ; P=0.004\right)$. Post-hoc comparisons indicated that females were in better condition in $1998(4.2 \pm 0.1 \mathrm{~g} / \mathrm{mm})$ than $1999(3.9 \pm 0.0 \mathrm{~g} / \mathrm{mm}), 2000(4.0 \pm 0.1 \mathrm{~g} / \mathrm{mm})$, $2001(3.9 \pm 0.1 \mathrm{~g} / \mathrm{mm})$, and $2002(3.9 \pm 0.1 \mathrm{~g} /$ $\mathrm{mm})$. Mean adult body condition $(4.1 \pm 0.0 \mathrm{~g} /$ $\mathrm{mm}$ ) was $4 \%$ greater than yearling body condition $(3.9 \pm 0.0 \mathrm{~g} / \mathrm{mm})$ during $1998-2003$.

\section{Nesting Parameters}

On average, the first Mallard nest of the season was initiated on 12 April, and the nesting season lasted 88 days. Typically, nests were terminated (i.e., hatched or destroyed) by 9 July (Table 5). One female initiated 4 nests in 1998, and all of these were unsuccessful. Mean number of nests/nesting female within year and age classes was variable (Table 6), but a significant year/age interaction $\left(\mathrm{F}_{5,126}=2.92 ; P=0.016\right)$ prevented interpretation of main effects. However, adults $(n=79)$ generally initiated more nests $(1.65 \pm 0.08$ nests/female) than yearlings $\left(n=48 ; 1.31 \pm 0.08\right.$ nests/female; $\mathrm{F}_{1,126}=4.16$; $P=0.044)$.

Table 2. Status, breeding incidence, capture rates, and age ratios of resident Mallards (Anas platyrhynchos) monitored in west-central Illinois, 1998-2003.

\begin{tabular}{lrrrrrr} 
& \multicolumn{5}{c}{ Year } \\
\cline { 2 - 7 } Status & 1998 & 1999 & 2000 & 2001 & 2002 & 2003 \\
\hline Resident females & 28 & 37 & 32 & 12 & 19 & 20 \\
Nested and tracked successfully & 27 & 33 & 24 & 11 & 16 & 18 \\
Did not nest & 0 & 1 & 1 & 1 & 2 & 1 \\
Died before nesting & 0 & 2 & 1 & 0 & 0 & 1 \\
Radio failure & 1 & 1 & 4 & 0 & 0 & 0 \\
Nested but unsuccessfully tracked & 0 & 0 & 2 & 0 & 1 & 0 \\
Breeding incidence (\%) & 100.0 & 97.1 & 96.7 & 91.7 & 89.5 & 94.7 \\
Capture rate (females/trap-day) & 0.14 & 0.19 & 0.16 & 0.04 & 0.05 & 0.06 \\
Age ratios (yearling:adult) & 0.47 & 1.18 & 0.33 & 0.50 & 1.38 & 0.82 \\
Resident males & 10 & 16 & 9 & 4 & 11 & 11 \\
\hline
\end{tabular}

a When determining breeding incidence, females that died $(n=4)$ or experienced transmitter failure $(n=1)$ prior to nesting were excluded (e.g., only 1 of 4 females in 2000 with a faulty radio transmitter was excluded because failure occurred prior to nesting).

b Paired and captured with resident females. 

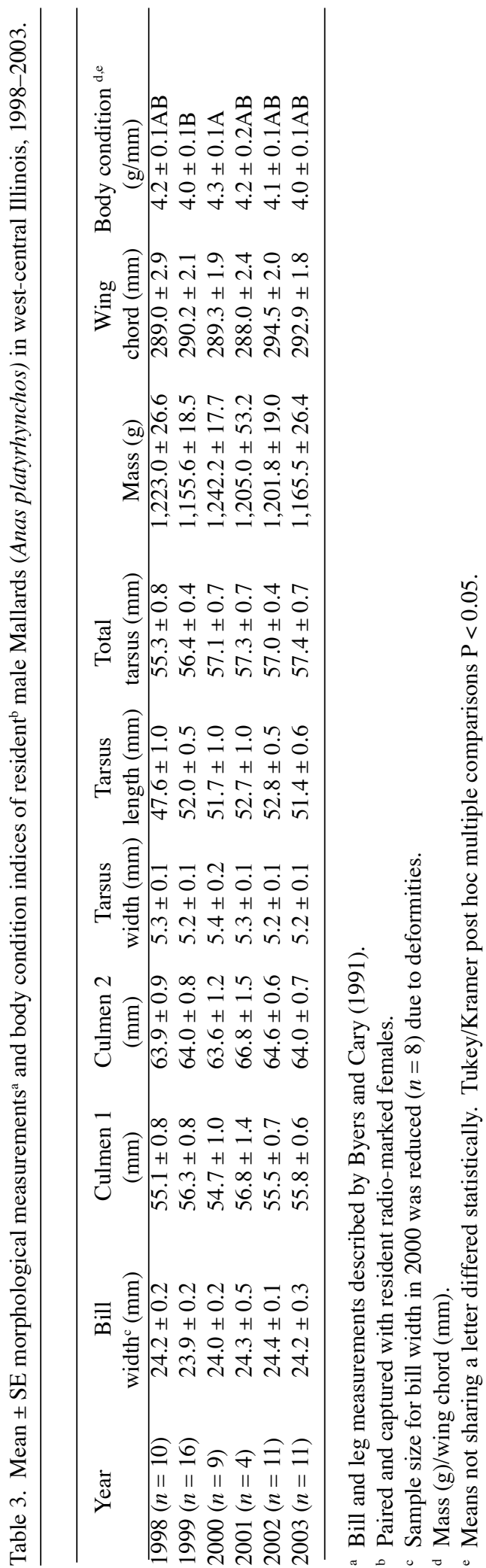

Mean initiation date for first nests varied during 1998-2003 (Table 7); for example, nest initiation was 2 weeks earlier in the spring of 1998 than during 1999 and $2002\left(\mathrm{~F}_{5,127}=4.74\right.$; $P<0.001)$. However, nest initiation date did not differ by female age $\left(\mathrm{F}_{1,127}=2.24 ; P=\right.$ $0.137)$. The majority (75\%) of all nests $(n=$ 195) were initiated by 20 May during 1998 2003 (Fig. 2); therefore, the majority of nests were predicted to hatch by 24 June.

Incubated clutch size of 66 first nest attempts ranged from $4-12$ eggs $(\bar{x}=9.4 \pm 0.2$ eggs $)$ and did not differ by age $\left(\mathrm{F}_{1,65}=2.04 ; P=\right.$ $0.158)$ or year $\left(\mathrm{F}_{5,65}=0.50 ; P=0.777\right)$. Clutch size of 19 second nests averaged $8.8 \pm 0.4$ eggs, and 3 third nest attempts contained 10 eggs each. Mean clutch size for all nests was $9.3 \pm$ 0.2 eggs $(n=88)$. We did not detect a relationship between incubated clutch size and nest initiation date $\left(\mathrm{F}_{1,87}=3.15 ; P=0.080\right)$, although the trend was generally declining (Fig. 3).

Egg hatchability was $92.1 \%(n=329$ eggs; $n=37$ hatched nests), ranging from $77.8 \%$ in 2001 to $97.6 \%$ in 1998, and was fairly consistent in other years $(93.6 \%$ in $1999,90.5 \%$ in 2000, $90.2 \%$ in 2002, and $95.5 \%$ in 2003). Yearlings hatched a greater proportion of eggs (97.3\%; $n=109$ eggs) than adults $(89.6 \% ; n=$ 220 eggs $)\left(\mathrm{G}_{1}=4.93 ; P=0.026\right)$. Overall, $<1$ egg failed to hatch per successful nest (Photo $5)$.

We evaluated renesting effort of 77 females that survived an unsuccessful first nesting attempt. The proportion of females each year that renested ranged from 50.0-85.7\%, and adults were more likely to renest $(75.0 \% ; n=$ 52) than yearlings $(48.0 \% ; n=25)\left(\mathrm{G}_{1}=4.36\right.$; $P=0.037)$. Additionally, renesting females initiated first nests ( $n=51$; April 27; SE 1.4 days) earlier than those not renesting $(n=26$; May 4; $\mathrm{SE}=2.0$ days $)\left(t_{75}=3.03 ; P=0.003\right)$.

We considered 3 of 4 models formulated to explain variation in nest survival to be competitive $\left(\Delta \mathrm{AIC}_{c} \leq 2.0\right.$; Table 8$)$. The best approximating model was the intercept-only model, which indicated a constant nest-survival rate of $19.6 \%$ during our study (Table 9). The second-best model was $0.5 \mathrm{AIC}_{c}$ units from the best model and included NESTINIT, which suggested nest survival declined slightly over 


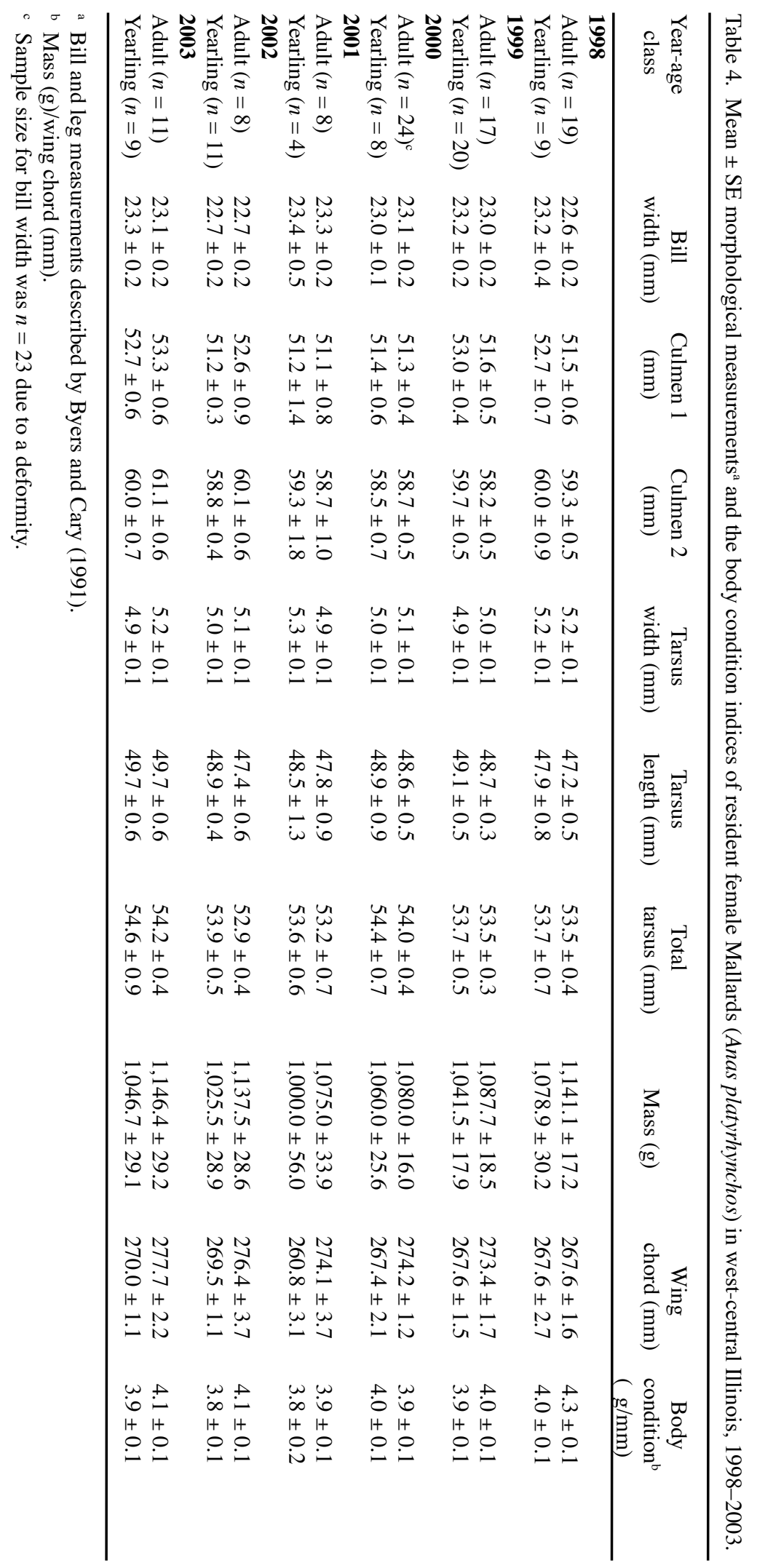


Table 5. Mallard (Anas platyrhynchos) nesting season dates and lengths in west-central Illinois, 1998-2003.

\begin{tabular}{cccc}
\hline Year & First nest initiation & Last nest hatched or destroyed & Nesting season length (days) \\
\hline 1998 & $4 \mathrm{Apr}$ & $1 \mathrm{Jul}$ & 89 \\
1999 & $6 \mathrm{Apr}$ & $17 \mathrm{Jul}$ & 103 \\
2000 & $12 \mathrm{Apr}$ & $20 \mathrm{Jul}$ & 100 \\
2001 & $14 \mathrm{Apr}$ & $30 \mathrm{Jun}$ & 78 \\
2002 & $22 \mathrm{Apr}$ & $7 \mathrm{Jul}$ & 77 \\
2003 & $17 \mathrm{Apr}$ & $6 \mathrm{Jul}$ & 81 \\
\hline
\end{tabular}

Table 6. Number of nest attempts by resident Mallards (Anas platyrhynchos) in west-central Illinois, 1998-2003.

\begin{tabular}{llclc}
\hline & & & \multicolumn{2}{c}{ Nest attempts } \\
\cline { 3 - 5 } Year & Age & Females & 1.56 & Sean \\
\hline 1998 & Adult & 18 & 2.13 & 0.22 \\
& Yearling & 8 & 1.67 & 0.23 \\
1999 & Adult & 15 & 1.12 & 0.19 \\
& Yearling & 17 & 1.74 & 0.08 \\
2000 & Adult & 19 & 1.40 & 0.15 \\
& Yearling & 5 & 1.50 & 0.24 \\
2001 & Adult & 8 & 1.33 & 0.27 \\
& Yearling & 3 & 1.38 & 0.33 \\
2002 & Adult & 8 & 1.13 & 0.18 \\
& Yearling & 8 & 1.91 & 0.13 \\
2003 & Adult & 11 & 1.00 & 0.25 \\
& Yearling & 7 & & 0.00 \\
\hline
\end{tabular}

Table 7. Julian day and date of nest initiation for first nest attempts by resident Mallards (Anas platyrhynchos) in west-central Illinois, 1998-2003.

\begin{tabular}{lllll}
\hline & & & \multicolumn{2}{c}{ Julian day $^{\mathrm{a}}$} \\
\cline { 3 - 5 } Year & $n$ & Date & Mean & SE \\
\hline 1998 & 25 & $22 \mathrm{Apr}$ & $112 \mathrm{~A}$ & 2.5 \\
1999 & 33 & $6 \mathrm{May}$ & $126 \mathrm{~B}$ & 2.2 \\
2000 & $30 \mathrm{Apr}$ & $120 \mathrm{AB}$ & 2.2 \\
2001 & 25 & $29 \mathrm{Apr}$ & $119 \mathrm{AB}$ & 3.7 \\
2002 & 11 & $6 \mathrm{May}$ & $126 \mathrm{~B}$ & 2.2 \\
2003 & 16 & $29 \mathrm{Apr}$ & $119 \mathrm{AB}$ & 1.4 \\
\hline
\end{tabular}

${ }^{a}$ Column means not sharing the same letter differed significantly, Tukey/Kramer post hoc tests. 


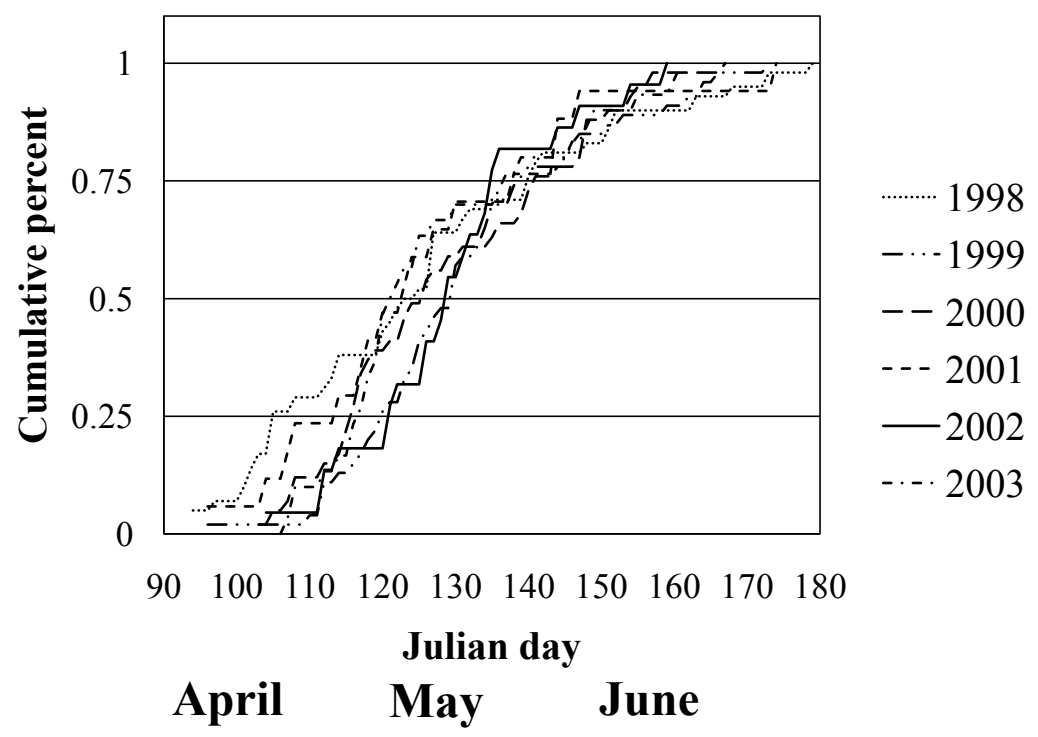

Figure 2. Percentage of Mallard (Anas platyrhynchos) nests initiated by Julian day in west-central Illinois, 1998-2003.

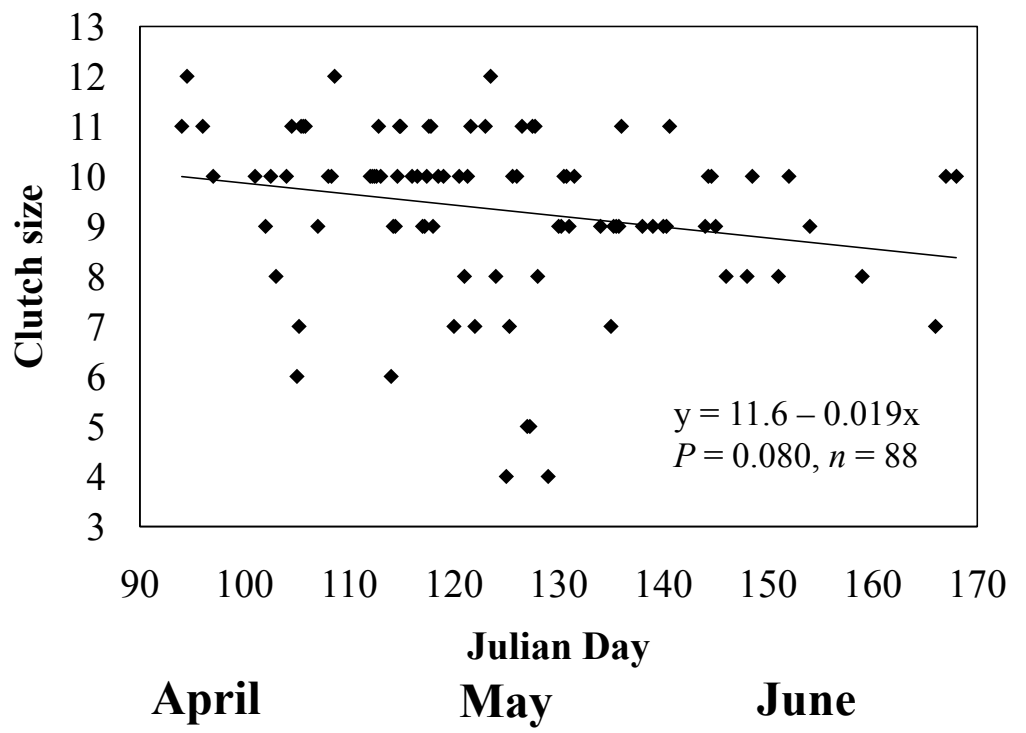

Figure 3. Regression of clutch size on nest initiation date for Mallards (Anas platyrhynchos) in west-central Illinois, 1998-2003. 


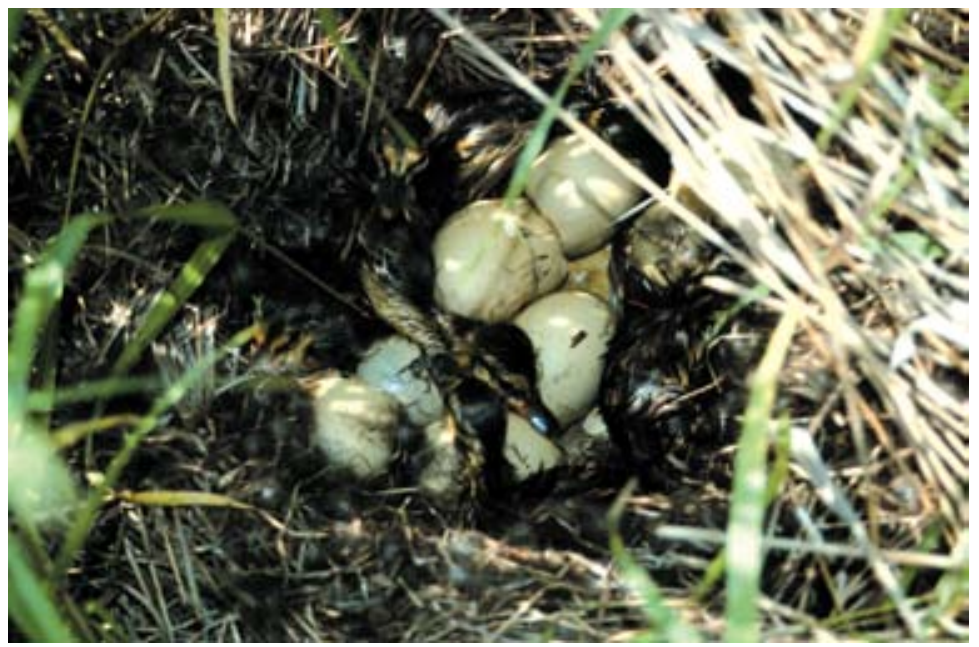

Photo 5. Hatched Mallard (Anas platyrhynchos) clutch at the Metropolitan Water Reclamation District of Greater Chicago (MWRD) near Cuba, Illinois. Photo by Aaron P. Yetter.

Table 8. Candidate models to explain variation in Mallard (Anas platyrhynchos) nest success in west-central Illinois, 1998-2003, ranked by second-order Akaike's information criterion (AIC ${ }_{c}$ ). Also included are the number of estimable parameters $(K),-2 \log$ likelihood score $(-2 \log )$, and model weight $\left(w_{i}\right)$.

\begin{tabular}{lccccc}
\hline Model & $K$ & $-2 \log$ & $\mathrm{AIC}_{c}$ & $\Delta \mathrm{AIC}_{c}$ & $w_{i}$ \\
\hline S(.) & 2 & 186.8 & 190.9 & 0.0 & 0.462 \\
S(NESTINIT) & 3 & 185.3 & 191.4 & 0.5 & 0.356 \\
S(AGE) & 3 & 186.6 & 192.8 & 1.9 & 0.182 \\
S(YEAR) & 7 & 179.9 & 194.5 & 3.7 & 0.074 \\
\hline
\end{tabular}

Table 9. Nest and hen success of Mallards (Anas platyrhynchos) in west-central Illinois, 1998-2003. Values are back-transformed logit estimates from generalized linear mixed models.

\begin{tabular}{|c|c|c|c|c|c|c|c|c|}
\hline \multirow[b]{2}{*}{ Year } & \multicolumn{4}{|c|}{ Nest success } & \multicolumn{4}{|c|}{ Hen success } \\
\hline & $n$ & $\%$ & LCL & UCL & $n$ & $\%$ & LCL & UCL \\
\hline 1998 & 38 & 26.3 & 14.7 & 42.5 & 26 & 38.5 & 22.0 & 58.1 \\
\hline 1999 & 45 & 15.6 & 7.6 & 29.3 & 33 & 21.2 & 10.4 & 38.5 \\
\hline 2000 & 41 & 9.8 & 3.7 & 23.4 & 26 & 15.4 & 5.8 & 34.8 \\
\hline 2001 & 16 & 25.0 & 9.6 & 51.0 & 11 & 36.4 & 14.2 & 66.4 \\
\hline 2002 & 21 & 33.3 & 16.7 & 55.5 & 17 & 41.2 & 20.9 & 65.0 \\
\hline 2003 & 28 & 17.9 & 7.6 & 36.5 & 18 & 27.8 & 11.9 & 52.2 \\
\hline Yearlings & 60 & 21.6 & 12.6 & 34.3 & 81 & 26.0 & 15.5 & 40.3 \\
\hline Adults & 129 & 18.7 & 12.7 & 27.0 & 50 & 29.7 & 20.4 & 41.1 \\
\hline Overall & 189 & 19.6 & 14.1 & 26.7 & 131 & 28.3 & 20.9 & 37.1 \\
\hline
\end{tabular}

time; however, the confidence interval about the parameter estimate overlapped zero, indicating the relationship was weakly supported. The third-best model $\left(\triangle \mathrm{AIC}_{c}=1.9\right.$; Table 8$)$ included AGE, and indicated that yearling nest survival was slightly greater $(21.6 \%)$ than that of adults $(18.7 \%)$, but the difference was not supported due to overlapping $95 \%$ confidence intervals. The final model included only YEAR and captured only $7.4 \%$ of the model weight $\left(w_{i}\right.$; Table 8$)$, suggesting the model was not supported. Coyotes (Canis latrans) and raccoons (Procyon lotor) were the most commonly identified nest predators (Table 10). Nine of 200 nests $(4.5 \%)$ failed as a result of nonresearcher human activities (e.g., abandoned, mowed, hayed, trampled, and 1 nest failed after the hen was killed by an automobile); 4 of those were specifically lost to agricultural practices.

Similar to models of nest success, the best approximating model of hen success was 
Table 10. Fate of Mallard (Anas platyrhynchos) nests in west-central Illinois, 1998-2003.

\begin{tabular}{|c|c|c|c|c|c|c|c|}
\hline \multirow[b]{2}{*}{ Nest fate } & \multicolumn{7}{|c|}{ Number of nests by year } \\
\hline & 1998 & 1999 & 2000 & 2001 & 2002 & 2003 & Total \\
\hline Hatched & 10 & 7 & 4 & 4 & 7 & 5 & 37 \\
\hline Coyote (Canis latrans) & 15 & 10 & 7 & 0 & 3 & 2 & 37 \\
\hline Raccoon (Procyon lotor) & 8 & 3 & 5 & 2 & 4 & 0 & 22 \\
\hline Mink (Mustela vison) & 0 & 0 & 1 & 1 & 0 & 0 & 2 \\
\hline Snake & 1 & 3 & 1 & 1 & 1 & 0 & 7 \\
\hline Striped skunk (Mephitis mephitis) & 0 & 0 & 1 & 0 & 0 & 0 & 1 \\
\hline Opossum (Didelphis virginiana) & 0 & 0 & 1 & 1 & 0 & 0 & 2 \\
\hline Turtle & 0 & 1 & 0 & 0 & 0 & 0 & 1 \\
\hline Unknown predator & 7 & 19 & 25 & 6 & 4 & 20 & 81 \\
\hline Abandoned $^{\mathrm{a}}$ & 6 & 1 & 0 & 0 & 0 & 1 & 8 \\
\hline Mowed/hayed & 1 & 3 & 0 & 0 & 1 & 0 & 5 \\
\hline Agricultural equipment & 0 & 0 & 0 & 1 & 0 & 0 & 1 \\
\hline Railroad maintenance & 0 & 0 & 0 & 0 & 1 & 0 & 1 \\
\hline Auto collision ${ }^{\mathrm{b}}$ & 0 & 0 & 0 & 0 & 1 & 0 & 1 \\
\hline Total & 48 & 47 & 45 & 16 & 22 & 28 & 206 \\
\hline
\end{tabular}

${ }^{a}$ Five nests were abandoned due to researcher disturbance in 1998 and one in 1999. These nests were used in analyses where appropriate.

${ }^{\mathrm{b}}$ One nest failed because the female was found dead on a roadway; a presumed roadkill.

Table 11. Candidate models to explain variation in Mallard (Anas platyrhynchos) hen success in west-central Illinois, 1998-2003, ranked by second-order Akaike's information criterion (AIC $)$. Also included are the number of estimable parameters $(K),-2 \log$ likelihood score $(-2 \log )$, and model weight $\left(w_{i}\right)$.

\begin{tabular}{lccccc}
\hline Model & $K$ & $-2 \mathrm{Log}$ & $\mathrm{AIC}_{c}$ & $\Delta \mathrm{AIC}_{c}$ & $w_{i}$ \\
\hline S(.) & 2 & 155.9 & 160.0 & 0.0 & 0.674 \\
S(AGE) & 3 & 155.7 & 161.9 & 1.9 & 0.262 \\
S(YEAR ) & 7 & 149.8 & 164.7 & 4.7 & 0.065 \\
\hline
\end{tabular}

Table 12. Apparent nest success, habitat availability, and habitat use of nesting Mallards (Anas platyrhynchos, $n=167$ nests) at the Prairie Plan area of the Metropolitan Water Reclamation District of Greater Chicago (MWRD) in west-central Illinois, 1998-2003.

\begin{tabular}{lcccc}
\hline Habitat type & $\begin{array}{c}\text { Habitat } \\
\text { availability }(\%)\end{array}$ & Nests & $\begin{array}{c}\text { Percent } \\
\text { of nests }\end{array}$ & $\begin{array}{c}\text { Percent } \\
\text { hatched }\end{array}$ \\
\hline Cropland & 27.3 & 4 & 2.0 & 25.0 \\
Forest & 24.2 & 5 & 2.9 & 0.0 \\
Idle grassland & 14.5 & 93 & 55.7 & 25.8 \\
Hay/idle mowed & 14.5 & 44 & 26.4 & 11.4 \\
Pasture & 10.0 & 10 & 6.0 & 20.0 \\
Scrub & 4.9 & 10 & 6.0 & 20.0 \\
Pond & 4.7 & 1 & 0.6 & 0.0 \\
\hline
\end{tabular}


the intercept-only model (Table 11), which indicated a constant hen success rate of $28.3 \%$ (Table 9). The model including AGE was 1.9 $\mathrm{AIC}_{c}$ units from the best model, and parameter estimates suggested adults were slightly more successful than yearlings (Tables 9 and 11). However, confidence intervals overlapped considerably, indicating no substantial difference between age classes. The third-best model included YEAR but captured only $6.5 \%$ of model weight (Table 11).

We classified habitats at 167 nest sites at MWRD into 7 broad classifications (Table 12). Nest success did not differ among these categories $\left(\mathrm{G}_{6}=6.90 ; P=0.330\right)$, even though habitat-specific nest success ranged from 0.0 to $25.8 \%$. Nest success was low in hay/idle mowed habitats $(11.4 \%)$; however, only 5 of 39 nests $(12.8 \%)$ that failed succumbed to mechanical destruction (Table 10). Idle grassland was the most-used nesting habitat (56\% of nests) and had the highest apparent nest success rate (Table 12). Hay/idle mowed areas contained $26 \%$ of nests, and when combined with idle grassland, these 2 habitat classifications hosted $82 \%$ of all Mallard nests. Although the difference in nest success between grassland and hay/idle mowed was not statistically significant, this difference may have biologi- cal implications. Together, scrub and pasture contained $12 \%$ of nests. Wetland, forest, and cropland were rarely used, and all 4 nests in cropland were in rye (Secale cereale).

\section{Brood Size}

Mean brood size at hatch was $8.2 \pm 0.3$ ducklings (range: $4-12 ; n=37$ ) and did not differ among years $\left(\mathrm{F}_{5,36}=0.62 ; P=0.686\right)$; however, annual sample sizes were small (range: 4-10 broods/year). Brood size on the $17^{\text {th }}$ day after hatch averaged $3.0 \pm 0.6$ ducklings $(n=$ 21 ) including 7 females that experienced total brood loss; this value was $36.6 \%$ of the brood size at hatch.

\section{Survival}

Survival rates (20 days) for 32 broods during 1998-2003 ranged from $0.643 \pm 0.210$ (2002) to $1.000 \pm 0.000$ (2001) and did not differ among years $\left(\chi_{5}^{2}=0.96 ; P=0.966\right)$. The overall brood survival estimate $(n=32)$ was 0.759 \pm 0.081 and included 7 females that lost their entire brood (Photo 6, Fig. 4).

We included 251 ducklings from 31 broods in survival analyses. The 20-day survival estimate was similar across years $\left(\chi_{5}^{2}=9.61\right.$; $P=0.087)$ and averaged $0.413 \pm 0.035$. Most duckling mortality $(63.4 \%, n=131)$ occurred within 5 days of hatch (Fig. 4), and $94.4 \%$ of

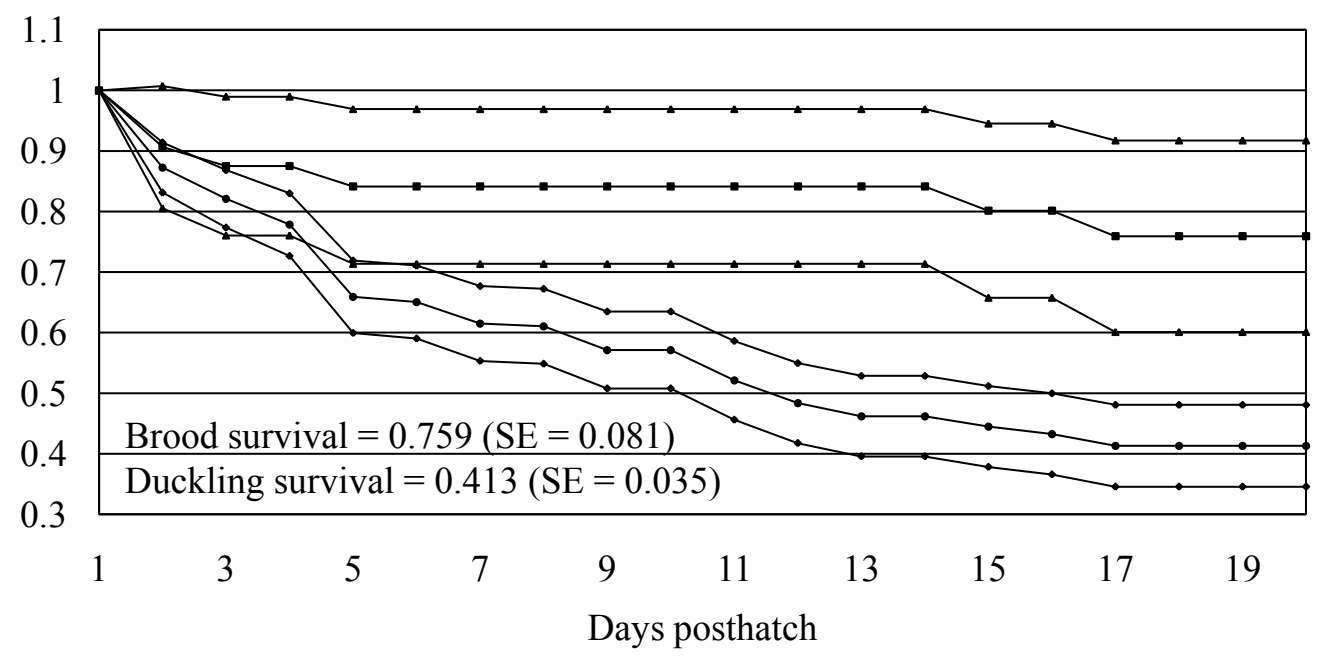

$\rightarrow$-Brood survival $\rightarrow$ Brood CI $95 \rightarrow$-Duckling survival $\rightarrow$-Duckling CI 95

Figure 4. Kaplan-Meier survival estimates of Mallard (Anas platyrhynchos) broods $(n=32)$ and ducklings ( $n=251)$ in west-central Illinois, 1998-2003. 


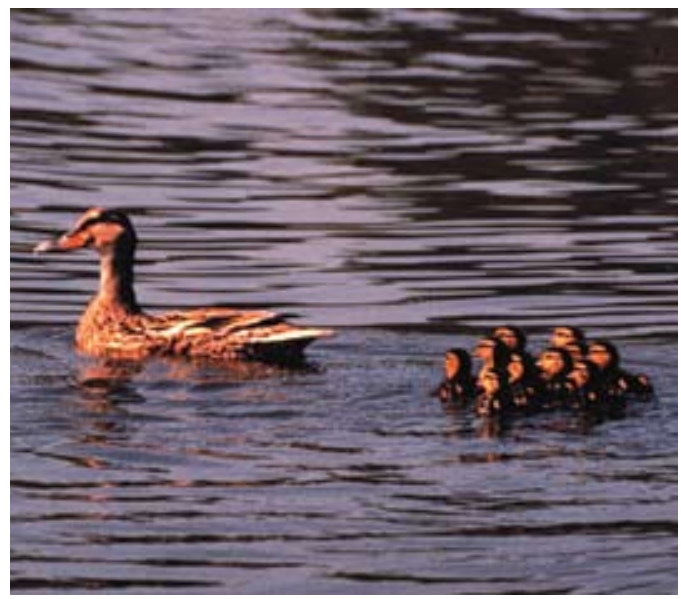

Photo 6. Mallard (Anas platyrhynchos) brood in west-central Illinois. Photo by Aaron P. Yetter.

mortalities occurred by the $13^{\text {th }}$ day.

Female survival during the breeding season ranged from 0.546-1.00 (Table 13) and did not differ by year $\left(\chi_{1}^{2}=0.93 ; P=0.335\right)$ or age $\left(\chi_{1}^{2}\right.$ $=1.33 ; P=0.248)$. Thirty-two of 148 females (21.6\%) died during the prenesting and nesting periods, and none were lost during brood rearing. Female survival averaged $0.710 \pm 0.096$ during 1998-2003. Twenty-five females were killed during 160 unsuccessful nest attempts; thus, the probability of mortality associated with a nest failure was $15.6 \%$.

\section{Recruitment}

We estimated that 125 of 303 ducklings survived to 20 days posthatch. Assuming a 50:50 sex ratio and no difference in survival between sexes, 62 female ducklings survived the period. Because 32 nesting females died during 19982003, we calculated that 1.9 female ducklings survived to 20 days for each female that died during the breeding season. Except for 1999, the number of female ducklings surviving to 20 days exceeded the number of nesting females that perished each year. However, 148 females were considered residents at the start of the breeding season, which resulted in the production of 0.4 female ducklings per female in the spring breeding population. Based on existing survival estimates for female Mallards banded in northern Illinois and Wisconsin and duckling survival estimates from this study, we determined annual recruitment ranged from 0.302 to 0.672 female ducklings/hen (Table 14). Assuming constant female and duckling survival rates among years, we estimated a recruitment rate of 0.613 female ducklings/hen was necessary to maintain a stable breeding population in west-central Illinois. We acknowledge that if duckling mortality from 20 days to fledge was considerable our estimates of recruitment would be biased high.

\section{DISCUSSION}

\section{Mass and Body Condition}

Body masses of prenesting Mallards in our study were comparable to those documented in New Jersey, Minnesota, and the Canadian Parklands of Alberta, Saskatchewan, and Manitoba (Figley and Van Druff 1982, Zicus and Rave 1998, Arnold et al. 2002). Our findings were nearly identical to those of Bellrose (1980), who reported that adult females averaged 1,107 $\mathrm{g}$ and immatures $1,048 \mathrm{~g}$, whereas adult and immature male Mallards averaged 1,247 $\mathrm{g}$ and $1,193 \mathrm{~g}$, respectively. However, female body mass in our study was 8-9\% less than assumed in the Mallard Productivity Model (1,200 g adults; $1,100 \mathrm{~g}$ yearlings) (Krapu and Doty 1979, Johnson et al. 1987). We suggest that the lack of high-quality emergent marshes and diverse wetland complexes in the strip-mined lands of west-central Illinois partially explains the lower prenesting body mass of Mallards in our study compared to prairie-nesting Mallards.

The body condition of prenesting females during this study resembled the fall condition indices of hunter-harvested female Mallards in Illinois (Hine et al. 1996). However, body condition of hunter-harvested Mallards may be biased low (Greenwood et al. 1986, Reinecke and Shaiffer 1988, Dufour et al. 1993). Spring body condition may be of particular concern in west-central Illinois because condition of prenesting females should have exceeded indices of fall-harvested Mallards.

\section{Nest Initiation}

Nest initiation dates for Mallards in our study were similar to other areas of North America, with variation between studies presumably due to latitude. Mallards in southeastern Il- 
Table 13. Kaplan-Meier survival estimates and 95\% confidence intervals for resident female Mallards (Anas platyrhynchos) by age class in west-central Illinois during March-August, 1998-2003.

\begin{tabular}{|c|c|c|c|c|c|}
\hline \multirow[b]{2}{*}{ Year } & \multirow{2}{*}{$\begin{array}{c}\text { Female } \\
\text { age }\end{array}$} & \multicolumn{2}{|c|}{ No. of females } & \multirow{2}{*}{$\begin{array}{l}\text { Female } \\
\text { survival }\end{array}$} & \multirow[b]{2}{*}{$95 \%$ CI } \\
\hline & & at risk & failed & & \\
\hline \multirow[t]{3}{*}{1998} & Adult & 19 & 4 & 0.624 & $0.249-0.999$ \\
\hline & Yearling & 9 & 2 & 0.750 & $0.472-1.000$ \\
\hline & Combined & 28 & 6 & 0.672 & $0.364-0.980$ \\
\hline \multirow[t]{3}{*}{1999} & Adult & 17 & 3 & 0.716 & $0.411-1.000$ \\
\hline & Yearling & 20 & 9 & 0.546 & $0.328-0.763$ \\
\hline & Combined & 37 & 12 & 0.599 & $0.337-0.862$ \\
\hline \multirow[t]{3}{*}{2000} & Adult & 24 & 4 & 0.793 & $0.589-0.997$ \\
\hline & Yearling & 8 & 1 & 0.857 & $0.617-1.000$ \\
\hline & Combined & 32 & 5 & 0.800 & $0.612-0.987$ \\
\hline \multirow[t]{3}{*}{2001} & Adult & 8 & 3 & 0.612 & $0.307-0.917$ \\
\hline & Yearling & 4 & 0 & 1.000 & - \\
\hline & Combined & 12 & 3 & 0.736 & $0.502-0.971$ \\
\hline \multirow[t]{3}{*}{2002} & Adult & 8 & 1 & 0.875 & $0.661-1.000$ \\
\hline & Yearling & 11 & 2 & 0.796 & $0.546-1.000$ \\
\hline & Combined & 19 & 3 & 0.817 & $0.620-1.000$ \\
\hline \multirow[t]{3}{*}{2003} & Adult & 11 & 1 & 0.909 & $0.747-1.000$ \\
\hline & Yearling & 9 & 2 & 0.735 & $0.454-1.000$ \\
\hline & Combined & 20 & 3 & 0.807 & $0.634-0.981$ \\
\hline 1998-2003 & Combined & 148 & 32 & 0.710 & $0.522-0.897$ \\
\hline
\end{tabular}

linois initiated nests between the last week of March and the first week of April (Louis 1999), whereas those in central California nested earlier, beginning in late February (McLandress et al. 1996). Mallards in Wisconsin initiated nests during the first week of April (Wheeler and March 1979), and nest initiation peaked the second week of May (Evrard 2002). Likewise, Mallards in northern Iowa had mean nest initiation dates of 11-21 May, with a range of 10 April-4 July (Fleskes 1986), and the onset of the Mallard nesting season in North and South Dakota was 8 April (Krapu et al. 2004).

The Mallard Productivity Model assumes a 120-day nesting season for determining recruitment in the Prairie Pothole Region (Johnson et al. 1986). This value exceeded the longest nesting season we observed by 17 days; however, a few unmarked females were known to be incubating nests well into July during our study (e.g., based on incidental brood sightings in August). In central North Dakota, Cowardin et al. (1985) identified a median nest initiation date of 18 May for adult and 20 May for yearling Mallards, and a median initiation date of 16 May was identified in Prairie Canada (Greenwood et al. 1995). In contrast, we found $75 \%$ of nests were initiated by 20 May. Similar to our findings, ducks initiated nesting in North Dakota roadsides during the third week of April. Only 4 nests were initiated after the first week of July, and all waterfowl nests were terminated by the second week of August (Voorhees and Cassel 1980). We suspect the shorter nesting season we observed, along with the previously discussed female body condition, may reflect the quality of strip-mined wetlands in west-central Illinois when compared with marshes of the Prairie Pothole Region. 


\section{Nesting Attempts}

The number of nesting attempts $(n=1.52)$ in west-central Illinois was slightly lower than previously published findings. In the aspen parklands of Canada, female Mallards carrying radio transmitters similar to those used in our study, initiated 1.44 nests/female, whereas females with abdominally implanted transmitters averaged 2.01 nests/female (Paquette et al. 1997). Mallards carrying abdominally implanted transmitters initiated 2.07 nests/female in southern Ontario (Hoekman et al. 2006a), and McPherson et al. (2003) reported 1.41 nests/ female from Mallards fitted with abdominally implanted transmitters in Alberta, Canada. However, McPherson et al. (2003) estimated they failed to detect $26 \%$ of the initiated Mallard nests, resulting in a corrected estimate of 1.91 nests/female. Our estimates of nest attempts should be considered conservative because external radio transmitters may have reduced nesting effort (Paquette et al. 1997). Additionally, some nest attempts may have gone undetected if nests were destroyed during early laying (McPherson et al. 2003); however, we monitored females daily and believe the number of undetected nests was low.

The Mallard Productivity Model predicted that 1.18 to 2.14 nests/female will be initiated in conditions ranging from dry to wet in a given year in the glaciated prairies of North America (Johnson et al. 1986). Our analysis of nesting attempts included a significant interaction between year and age class that prevented main-effects comparisons; however, our data did not indicate that a relationship existed between precipitation and nest attempts, despite considerable variation in rainfall at MWRD during January-May of the study period (range: 28 to $58 \mathrm{~cm}$; Josh DeWees, Metropolitan Water Reclamation District of Greater Chicago, pers. comm.). Nesting effort by adult females in 1998 was less than yearlings because 8 of 10 successful nests were hatched by adults, and 7 of these females hatched their first nest attempt. Thus, more adults successfully nested on their first attempt in 1998, thereby reducing renesting effort.
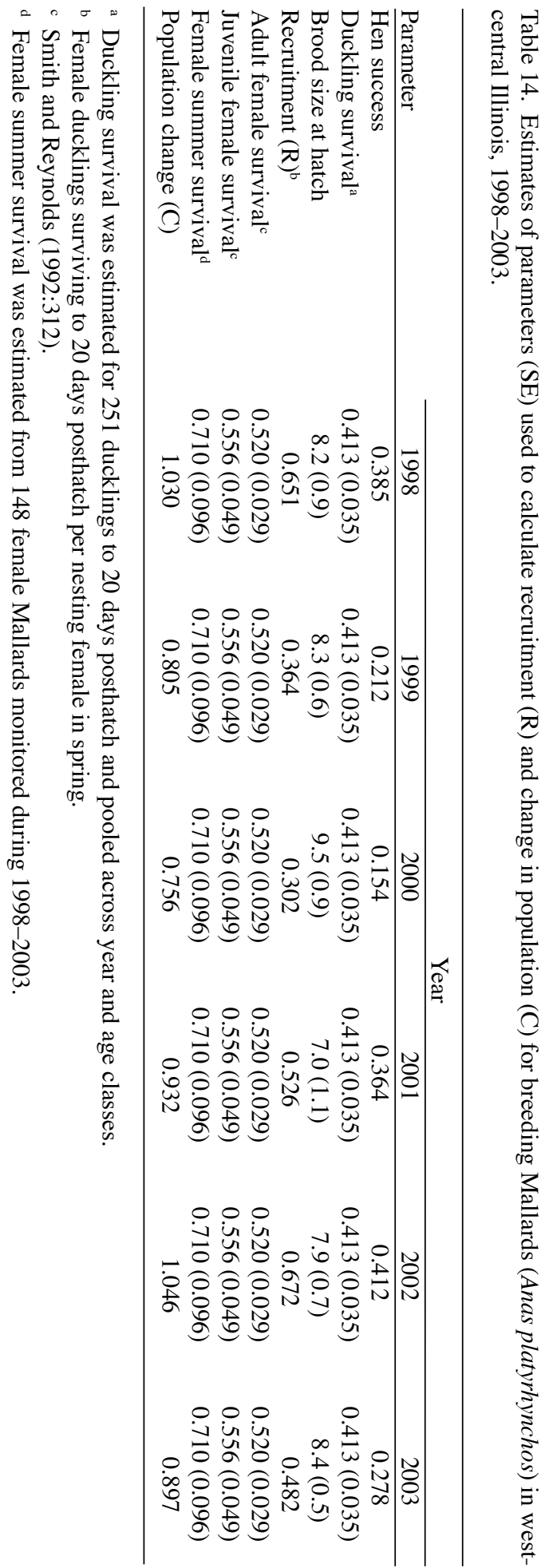


\section{Clutch Size}

Clutch size in Mallards has been extensively documented, and the average clutch size in our study (9.4 eggs) was within the documented range. In a concurrent Mallard investigation in southeastern Illinois, Louis (1999) recorded an average clutch size of 10.7 eggs. Mallards averaged 9.7 eggs/clutch in the suburban environments near Chicago, Illinois (R.A. Montgomery, Max McGraw Wildlife Foundation, pers. com.). Bellrose (1980) noted that clutch size in Mallards was variable and averaged 9.0 eggs/clutch. Other investigations from throughout North America reported average clutch sizes ranging from 7.1 to 11.7 eggs (Figley and Van Druff 1982, Krapu et al. 1983, Cowardin et al. 1985, Fleskes 1986, Clark et al. 1988, Krementz et al. 1992, Dwyer and Baldassarre 1993, McLandress et al. 1996, Yerkes and Bluhm 1998, Zicus and Rave 1998, Artmann 1999, Riviere 1999, Petrie et al. 2000, Nelson and Wetzel 2001, Ball et al. 2002, Evrard 2002, Zicus et al. 2003a, Hoekman et al. 2006a, Coluccy et al. 2008).

Mallard clutch size is believed to be negatively associated with nest initiation date and successive nest attempts (Johnson et al. 1987, McLandress et al. 1996). Declines in Mallard clutch sizes of 0.02 to $0.07 \mathrm{egg} / \mathrm{day}$ during the nesting season were reported in North Dakota, Minnesota, and California (Krapu et al. 1983, Cowardin et al. 1985, McLandress et al. 1996, Ball et al. 2002, Zicus et al. 2003a). We did not detect a trend in the incubated clutch size with increasing nest initiation date, but the relationship approached significance $(P=0.080)$.

Females generally laid 1 egg/day, and we documented 4 occasions when females skipped laying during inclement weather, which occurs commonly among North American dabbling ducks (tribe Anatini; Alisauskas and Ankney 1992). Interestingly, we observed 1 female that failed to lay an egg for 5 consecutive days before returning to complete her clutch and hatch 10 of 11 eggs.

\section{Egg Hatchability}

The average egg-success rate (i.e., hatchability; $92.1 \%$ ) in our study was comparable to rates previously reported. For example, Bellrose (1980) compiled data from various studies and reported an egg success rate of $93.8 \%$. Mallards hatched $89.1 \%$ of eggs during the mid1980s in north-central Montana (Orthmeyer and Ball 1990), and hatching success was 93.8-97.7\% in Minnesota (Zicus et al. 2003b). Mallards at Union Slough National Wildlife Refuge in northern Iowa had an unusually high egg success rate of 99.0\% (Fleskes 1986). Because estimated egg hatchability during our study was similar to previously reported estimates, we believe egg success did not limit Mallard recruitment in west-central Illinois.

\section{Renesting Effort}

Mallards will renest when adequate forage is available (Bellrose 1980, Titman 1981, Swanson et al. 1985), and captive wild Mallards have been induced to lay up to 5 clutches following egg removal (Swanson et al. 1986). Renesting effort by Mallards (50.0-85.7\%) in our study was similar to the renesting rate of females with destroyed nests in Vermont (57\%; Coulter and Miller 1968) and New Brunswick (50\%; Petrie et al. 2000). In contrast, Dzubin and Gollop (1972) estimated lower renesting rates (30-48\%) by Mallards in Saskatchewan and Manitoba, and Bergmann et al. (1994) detected no renesting of females with failed nests in eastern South Dakota. However, backpack radio transmitters used in their study have been demonstrated to negatively influence breeding effort in dabbling ducks (Pietz et al. 1993, Rotella et al. 1993). Based upon results from these studies, we suggest that renesting rates of Mallards we observed were adequate to sustain Mallard populations in west-central Illinois.

Double-brooding is commonly defined as successfully hatching 2 nests in a breeding season. This phenomenon is considered rare in wild Mallards, but may be more common in suburban areas (Errington 1934, Figley and Van Druff 1982). Indeed, Mallards nesting in urban New Jersey commonly renested after total brood loss (Figley and Van Druff 1982). Double brooding by wild Mallards has been reported by Doty (1975) in North Dakota, Stafford et al. (2001) in South Dakota, and Ol- 
sen et al. (2003) in Ohio. No females who lost their broods renested during our study. Continuous laying by Mallards is also uncommon. However, Arnold et al. (2002) reported that $9.1 \%(n=3,064)$ of radiomarked Mallards renested immediately after an unsuccessful nest attempt. We documented continuous laying by only 1 of 77 (1.3\%) females surviving an unsuccessful first-nest attempt.

\section{Nest Success}

Annual estimates of nest success in westcentral Illinois ranged from 9.8 to $33.3 \%$ and averaged $19.6 \%$. Bellrose (1980) reported that apparent nest success of Mallards was $24.8 \%$ in the Great Lakes states, which was somewhat greater than our estimate. Hoekman et al. (2006a) estimated nest survival of $13.0 \%$ for Mallards in southern Ontario, and Greenwood et al. (1987) reported relatively low nest success $(12 \%)$ in Prairie Canada, concluding that nest success was least during drought years. Conversely, Drever et al. (2004) modeled duck nest success in the Prairie Pothole Region over many years (1935-2000) and suggested nest success may have been greater during or shortly after drought years. The authors implied that this may have been due to drought-related changes in predator dynamics or because waterfowl populations contained more experienced adult breeders in dry years. Clearly, the relationship between precipitation and nest success is somewhat uncertain. Nonetheless, we note that nest success during our study was least $(9.8 \%)$ during the driest year and with the lowest age ratios ( 0.33 yearlings:adult). However, many factors (i.e., wetland dynamics, predator communities, and breeding duck densities) may be contributing to these differences in nest success rates.

Beauchamp et al. (1996) reported that Mayfield-corrected estimates of nest success of 5 species of ducks in the prairies had declined compared to rates (21-33\%) observed during the 1930s and 1950s. This reduction was partially attributed to habitat loss and agriculture (Cowardin et al. 1985, Klett et al. 1988, Greenwood et al. 1995, Beauchamp et al. 1996). Although we estimated grasslands (idle grassland and hay/idle mowed areas) represented $29 \%$ of the landscape at MWRD, much of Illinois' tallgrass prairie has been destroyed (Neely and Heister 1987, Illinois Department of Energy and Natural Resources 1994). We suggest that the low quality of grassland vegetation (i.e., smooth brome and meadow fescue), combined with extensive mowing and haying activities at MWRD, likely suppressed nest success rates in our study.

Some authors have suggested that duck nest success is dynamic and may decrease with increasing nest density (Livezey 1981, Fleskes 1986, Evrard 2002). We observed a similar trend, although nest densities we observed were generally less than the aforementioned studies. Specifically, nest survival was lower (9.8 to 26.3\%) during 1998-2000, when the density of breeding Mallards (indicated by the female capture rate; Table 2) was greatest. Nest survival was greater during 2001-2003 (17.9-33.3\%) when we perceived lower breeding densities.

Nest success has been identified as the most critical component of duck production (Cowardin and Johnson 1979, Cowardin et al. 1985, Johnson et al. 1987, Klett et al. 1988, Hoekman et al. 2002). We reviewed published estimates of nest success from various regions, years, and methods (Table 15) and found that Mallard nest success was highly variable. In their landmark study conducted in North Dakota, Cowardin et al. (1985) estimated Mallard nest success (Mayfield-Johnson) at $8.5 \%$ in agricultural environments; they predicted that a nest success rate of $15 \%$ was needed to maintain stable Mallard populations in that state. Gatti (1987), however, suggested that Mallards in Wisconsin required a $20 \%$ Mayfield nest success rate to maintain stable populations. Similarly, Evrard (2002) described a stable Mallard breeding population in Wisconsin that had an estimated Mayfield nest success rate of $21.6 \%$ during 1982-1990. Nest survival in west-central Illinois was similar to these levels (15.6- 33.3\%) in most years, but fell well below these thresholds in 2000.

\section{Nesting Habitat Use}

Mallards will nest in a variety of standing, 
Table 15. Comparison of Mallard (Anas platyrhynchos) nest success rates from various geographic locations, methods of calculation, and years, 1952-2003.

\begin{tabular}{|c|c|c|c|c|}
\hline Source & Location & Method $^{\mathrm{a}}$ & Years & $\begin{array}{l}\text { Success } \\
\text { rate }(\%)\end{array}$ \\
\hline Lee et al. 1964 & Minnesota & Apparent & $1957-1960$ & $31-42$ \\
\hline Duebbert 1969 & South Dakota & Apparent & 1968 & 82.6 \\
\hline Smith 1971 & Alberta & Apparent & $1952-1965$ & 42 \\
\hline Stoudt 1971 & Saskatchewan & Apparent & $1952-1965$ & 30 \\
\hline Voorhees and Cassel 1980 & North Dakota & Apparent & $1968-1973$ & 47 \\
\hline Cowardin et al. 1985 & North Dakota & Mayfield-Johnson & 1977-1980 & 8.5 \\
\hline Fleskes 1986 & Iowa & Mayfield & 1984-1985 & 9 \\
\hline Greenwood et al. 1987 & $\begin{array}{l}\text { Alberta, Saskatchewan, } \\
\text { and Manitoba }\end{array}$ & Mayfield-Johnson & 1982-1985 & 12 \\
\hline Klett et al. 1988 & $\begin{array}{l}\text { Western Minnesota } \\
\text { Eastern North Dakota } \\
\text { Central North Dakota } \\
\text { Eastern South Dakota } \\
\text { Central South Dakota } \\
\text { North Dakota }\end{array}$ & $\begin{array}{l}\text { Mayfield-Johnson } \\
\text { Mayfield-Johnson } \\
\text { Mayfield-Johnson } \\
\text { Mayfield-Johnson } \\
\text { Mayfield-Johnson } \\
\text { Apparent }\end{array}$ & $\begin{array}{l}1980-1984 \\
1966-1984 \\
1966-1984 \\
1966-1984 \\
1966-1974 \\
1966-1984\end{array}$ & $\begin{array}{c}5 \\
5 \\
8-11 \\
9-10 \\
19 \\
7\end{array}$ \\
\hline Clark et al. 1991 & Saskatchewan & Mayfield-Johnson & 1980-1986 & $1-45$ \\
\hline $\begin{array}{l}\text { Lokemoen and Woodward } \\
1992\end{array}$ & $\begin{array}{l}\text { North, and South Dakota, } \\
\text { and Montana }\end{array}$ & Apparent & 1985-1986 & 58 \\
\hline Arnold et al. 1993 & Minnesota, Manitoba & Mayfield-Johnson & 1985-1991 & $12.2-43.9$ \\
\hline Dwyer and Baldassarre 1993 & Northern New York & Mayfield-Johnson & 1990-1991 & 51 \\
\hline Kantrud 1993 & Minnesota and North Dakota & Mayfield-Johnson & 1989-1991 & $9.7-25.1$ \\
\hline Mauser and Jarvis 1994 & Northern California & Mayfield-Johnson & 1988-1990 & $25.4-68.8$ \\
\hline Greenwood et al. 1995 & Canadian Prairie Potholes & Mayfield-Johnson & 1982-1985 & 11 \\
\hline LaGrange et al. 1995 & North-central Iowa & Mayfield-Johnson & $1978-1990$ & $14-39$ \\
\hline Shaffer and Newton 1995 & $\begin{array}{l}\text { North, and South Dakota, } \\
\text { and Minnesota }\end{array}$ & Mayfield-Johnson & 1966-1989 & $6-20$ \\
\hline Kruse and Bowen 1996 & Northwestern North Dakota & Mayfield-Johnson & $1980-1988$ & 34.5 \\
\hline Maxson and Riggs 1996 & West-central Minnesota & Mayfield & 1985-1987 & 3.9 \\
\hline McLandress et al. 1996 & California & Mayfield-Johnson & 1985-1989 & $6.3-75.4$ \\
\hline
\end{tabular}


Table 15 continued from previous page

\begin{tabular}{|c|c|c|c|c|}
\hline Source & Location & Method $^{a}$ & Years & $\begin{array}{l}\text { Success } \\
\text { rate }(\%)\end{array}$ \\
\hline Louis 1999 & Illinois & Mayfield & 1997-1998 & 65 \\
\hline Riviere 1999 & California & Mayfield-Johnson & 1994-1995 & $35.0-45.4$ \\
\hline Petrie et al. 2000 & New Brunswick & Apparent & 1992-1994 & 31 \\
\hline \multirow{2}{*}{ Huseby et al. 2001} & \multirow[t]{2}{*}{ Northwest Minnesota } & Apparent & $1993-1995$ & 23 \\
\hline & & Mayfield-Johnson & 1993-1995 & 9.8 \\
\hline Nelson and Wetzel 2001 & $\begin{array}{l}\text { Pool } 8 \text { Mississippi River, } \\
\text { Wisconsin }\end{array}$ & Apparent & 1981-1999 & $35-87$ \\
\hline Reynolds et al. 2001 & North-central United States & Mayfield-Johnson & 1992-1995 & $12.1-13.6$ \\
\hline Evrard 2002 & Wisconsin & Mayfield-Johnson & 1982-1990 & 21.6 \\
\hline Hoekman et al. 2006a & Southern Ontario & $\begin{array}{l}\text { Known Fate Models } \\
\text { Program MARK }\end{array}$ & 1997-2000 & 13 \\
\hline Zimmerling et al. 2006 & Eastern Ontario & Apparent & 1999-2001 & $83-90$ \\
\hline Davis 2008 & Great Lakes states & Program MARK & $2001-2003$ & 15.6 \\
\hline
\end{tabular}

a Mayfield 1961, 1975; Johnson 1979; Klett et al. 1986

dense vegetation types (Bellrose 1980), and the Mallard Productivity Model predicted that $35.6 \%$ of nests were located in grassland habitats under average hydrologic conditions in the glaciated prairies (Johnson et al. 1986). In North and South Dakota and Minnesota, planted cover (i.e., vegetation established for wildlife or soil protection) was the preferred duck-nesting habitat (Klett et al. 1988). Despite limited areas of dense nesting cover at MWRD, our results were consistent with this trend, in that idle grassland (predominantly smooth brome) was the most frequently used nesting habitat and comprised $14.5 \%$ of the available nesting cover (Table 12).

Forage crops, such as alfalfa, provide suitable nesting cover if mowed later in spring (Lee et al. 1964); however, first hay cuttings in Illinois occur earlier now than in previous decades. Warner and Etter (1989) reported that the mean date of first hay cutting in east-central Illinois was 9 June in 1951, but preceded 1 June by 1986-1987. During our study, the first hay cut- ting occurred at the peak of the Mallard nesting season with over $63 \%$ of alfalfa hay in Illinois harvested by 10 June and more than $85 \%$ cut by 20 June (Illinois Agricultural Statistics Service 2004). We suspect the lower use of hay/idle mowed areas compared with grasslands in our study was due to the lack of residual nesting cover in early spring, likely a result of third hay cuttings that occurred in August and September 1998-2003 (Illinois Agricultural Statistics Service 2004).

Farming operations in North and South Dakota and Minnesota resulted in $27 \%$ of the duck nest failures in hayfields (Klett et al. 1988). Further, failure of nests in haylands was linked primarily to destruction by machinery in North Dakota; excluding mechanical mortality, nest success in hayfields was $82.4 \%$ (Cowardin et al. 1985). Surprisingly, only 4 of 31 (12.9\%) Mallard nests in hayfields during our study were destroyed by agricultural machinery, although many nests were depredated prior to haying operations. 
Many ducks nest in roadside right-of-ways in North and South Dakota and Minnesota (Higgins 1977, Voorhees and Cassel 1980, Sargeant 1981, Cowardin et al. 1985, Zicus and Rave 1998). We classified most roadside habitat as idle mowed, and found only 10 of 167 (6.0\%) nests along roadsides, although several nests were located in idle grasslands near $(<50 \mathrm{~m})$ roads. A common practice in Illinois was to mow roadsides many times during the growing season. Clearly, roadside grasslands would provide better nesting habitat if mowed only once each year, especially if mowing occurred after the nesting season (i.e., August; Herkert et al. 1993).

We found few overwater Mallard nests during our study. However, marsh nesting by Mallards was relatively common in Minnesota and the Great Lakes Region (Maxon and Riggs 1996, Davis 2008), and Cowardin et al. (1985) found $16 \%$ of nests of telemetered hens in wetlands in North Dakota. Mallard use of wetland vegetation for nesting was associated with dry years, when upland cover was limited (Cowardin et al. 1985). Conversely, Krapu et al. $(1979 b)$ reported that $66 \%$ of observed Mallard nests in North Dakota were located in wetlands, and indicated that wetland nesting was more common in wet years. Success of overwater nests can be high; Arnold et al. (1993) reported success of wetland nests in Manitoba was 3.6 times greater than upland nests. Prior coal mining activities at MWRD resulted in many wetlands with bottom contours that prohibited robust emergent vegetation, limiting opportunities for wetland nesting.

\section{Hen Success}

Hen success may be the best predictor of recruitment in birds, and Cowardin et al. (1985) estimated that a hen success rate of $31 \%$, similar to the $28.3 \%$ observed in our study, was required for stable Mallard populations in North Dakota. Similarly, the Mallard Productivity Model predicted stable populations in the prairies with a hen success rate of $28 \%$ under various assumptions of wetland conditions, female homing, and duckling survival (Johnson et al. 1986). Our estimates of hen success approached or exceeded this threshold in 4 of 6 years.
As with nest success, literature estimates of hen success indicated substantial spatial variability. Outstanding hen success rates were observed in northern California (44-76\%; Mauser and Jarvis 1994), New York (67\%; Dwyer and Baldassarre 1993), and New Brunswick (39\%; Petrie et al. 2000), and recent estimates of hen success in Ontario ranged from 25.4-46.0\% (Hoekman et al. 2006a, 2006b). In contrast, Mallard hen success was only $15.2 \%$ in North Dakota (Cowardin et al. 1985) and $18.4 \%$ in the parklands of Canada (Paquette et al. 1997). Thus, we suggest that hen success in west-central Illinois exceeded some previously reported estimates from the prairies and parklands, and was sufficient in some years to promote population stability and growth.

\section{Brood Size}

Initial brood size ( 8.2 ducklings) in westcentral Illinois was similar to investigations in North Dakota (6.8 ducklings; Talent et al. 1983) and south-central Saskatchewan (7.2-8.5 ducklings; Gendron and Clark 2002). However, urban Mallards in New Jersey had initial brood sizes of 7.8 to 10.0 ducklings (Figley and Van Druff 1982), and even greater initial brood sizes were observed in Iowa (9.6 ducklings; Fleskes 1986) and Wisconsin (9.0 ducklings; Evrard 2002). We believe initial brood size did not limit Mallard recruitment in west-central Illinois.

\section{Survival}

Our estimate of Mallard brood survival to 20 days was 0.76 and comparable to results from previous studies. For example, Yerkes and LaFarge (2002) reported that brood survival was 0.47 and 0.87 in Ohio and Michigan, respectively. Sixty-day brood survival was estimated at 0.72 for ducklings exiting nest structures in New York (Weik and Malecki 1999). Broods exiting overwater nesting structures had survival rates ( $\leq 20$ days) ranging from 0.71 to 1.00 in South Dakota (Stafford et al. 2002).

Mallard brood survival in Manitoba was better in wet than dry years (range: 0.34 to 0.70, Rotella and Ratti 1992a). Supporting this notion, Mallard broods in the Canadian PrairieParklands selected permanent and semiperma- 
nent wetlands on their ability to retain water throughout the brood-rearing season (Raven et al. 2007). However, females with nests near permanent wetlands in California were less successful at fledging young than females nesting near seasonal wetlands, which provided higher quality brood habitat (Mauser et al. 1994b, Krapu et al. 2000). Our study area had many semipermanent and permanent wetlands that were available during drought, and some appeared to provide high-quality brood habitat (i.e., adequate escape cover and abundant invertebrate forage). However, seasonal wetlands were less common, and many lacked the vegetative structure of prime brood-rearing areas. Consequently, Mallard broods at MWRD were likely drawn to vegetative structure that provided escape cover rather than water permanency. Nonetheless, we believe Mallard brood survival in west-central Illinois was sufficient for population growth when compared with previous research.

Duckling survival (20 days) in the present study was 0.413 with most duckling mortality (94.4\%) occurring within 13 days posthatch. Gendron and Clark (2002) reported an exceptional 30-day duckling survival rate of 0.595 from south-central Saskatchewan, which they attributed to excellent habitat conditions. They documented that most duckling loss occurred during the first 14 days. In southern Ontario, 30 -day survival was 0.40 , with $77 \%$ of duckling mortalities occurring within 8 days of hatch (Hoekman et al. 2004). Similarly, 86\% of duckling mortality occurred by 14 days posthatch in New York, even though ducklings hatched from overwater nesting structures (Weik and Malecki 1999).

In contrast to Illinois, duckling survival to 30 days on the Chesapeake Bay was 14-28\% (Krementz and Pendleton 1991), and 30-day duckling survival was only 0.22 for Mallards in southwestern Manitoba during the drought years of the late 1980s (Rotella and Ratti 1992a). Duckling survival in northern California was $18.1 \%$ to 10 days posthatch when wetlands were dewatered prior to peak hatch for moist-soil management practices (Fredrickson and Taylor 1982). However, survival (50 days) increased to 0.366 and 0.344 in 1989 and 1990, respectively, when wetlands remained flooded into June (Mauser et al. 1994a). Chouinard and Arnold (2007) estimated 30-day duckling survival to be 24.8\% during 1996-1997 in the San Joaquin Valley, California, and they found that broods preferred reverse-cycle wetlands that were flooded from March to August, a period when marshes are normally dry. The authors suggested reverse-cycle wetlands may have provided better food resources for ducklings in addition to escape cover when compared with more permanent wetland types.

In poorer quality brood habitats, such as large reservoirs, Salyer and Willms (1997) reported duckling survival to fledging ranged from 0 to $35 \%$, and concluded that high nest success was negated without quality brood habitat. Research has demonstrated that duckling survival varies with macroinvertebrate availability (Cox et al. 1998, Gunnarsson et al. 2004) and that macroinvertebrate availability increases as seasonally flooded ponds increase on the landscape (Neckles et al. 1990). Therefore, Krapu et al. $(2000,2006)$ suggested Mallard brood and duckling survival is enhanced during wet years in part due to increased area of seasonal ponds offering abundant macroinvertebrates that ducklings rely on for food.

Similar to Illinois, duckling survival to 56 days was $44 \%$ in New Brunswick (Petrie et al. 2000), and Huseby et al. (2001) reported that $42 \%$ of Mallard ducklings survived to fledge in a wild rice (Zizania aquatica) farming landscape in northwestern Minnesota. In Saskatchewan, Pearse and Ratti (2004) estimated 30-day duckling survival at $57 \%$ in areas following predator removal, whereas their estimates were lower $(36 \%)$ in areas without predator removal. Weik and Malecki (1999) observed a 60-day duckling survival rate of $36 \%$ in broods exiting overwater nesting structures. Similarly, Stafford and Pearse (2007) reported Mallard ducklings exiting overwater nesting structures in South Dakota experienced 30-day survival rates of $42-77 \%$. They attributed higher survival at one study site to better quality emergent vegetation that likely served as better escape and thermal cover. 
Duckling survival in our study was higher than reported estimates for some intensively farmed regions and areas experiencing drought; however, survival was considerably lower than reported for areas with high-quality, brood-rearing habitats. Hence, we speculate that duckling survival was limited by the lack of quality brood rearing wetlands at MWRD. Supporting this notion, Krapu et al. (2006) determined that duckling survival was enhanced during wet years when the number of seasonal wetlands on the landscape increased. Further, Hoekman et al. (2004) recommended enhancement and restoration of seasonal wetlands to increase duckling survival in southern Ontario. Coluccy et al. (2008) suggested management that improved duckling survival such as wetland rehabilitation and restoration was the most efficient way to enhance Mallard populations in the Great Lakes Region. We believe duckling survival was sufficient for maintaining Mallard populations in west-central Illinois but survival could have been enhanced by managing for emergent vegetation on brood-rearing wetlands and restoring seasonal wetland habitats on the landscape.

Female mortality, aside from hunting, is an important component of Mallard population dynamics (Sargeant et al. 1984). Recently, Hoekman et al. (2002) concluded that the population growth rate of mid-continent Mallards was most sensitive to nest success and female survival during the breeding season. Survival of females during nesting and brood rearing in west-central Illinois (0.71) was similar to estimates from other regions of North America. For example, Devries et al. (2003) found a 13 -week female survival rate of 0.76 in the Canadian Prairie Pothole Region. Other studies have shown that female survival was 0.65 to 0.84 in eastern Canada (Hoekman et al. 2006a, 2006b), 0.70 to 0.77 in the aspen parklands of Canada (Paquette et al. 1997), 0.74 in the Great Lakes Region (Coluccy et al. 2008), 0.81 in North Dakota (Cowardin et al. 1985), and 0.75 in north-central Minnesota (Kirby and Cowardin 1986).

Some regions experienced exceptional breeding season survival. Most notably, $85.6 \%$ of females in New Brunswick survived the breeding season (Petrie et al. 2000), as did $88.0 \%$ of females in a forested environment of northern New York (Dwyer and Baldassarre 1993).

These values contrasted the $50.9 \%$ summer survival rate of females monitored in Minnesota (Zicus and Rave 1998). Regional differences in predator communities, the composition of upland nesting cover, and availability of forage in wetland habitats likely influenced female survival during the nesting season.

We anticipated female survival might decrease during brood rearing, because there were few high-quality emergent wetlands that provided escape cover on our study site. However, we observed no mortality of females during the first 20 days of brood rearing, and consequently, our results contrast those of other studies. For instance, 2 of 22 females (9.1\%) died during brood rearing in New York (Dwyer and Baldassarre 1993), and Weik and Malecki (1999) estimated female survival to be 0.798 while rearing broods. Bergmann et al. (1994) reported that 10 of $60(16.7 \%)$ females died during brood rearing in eastern South Dakota. More similar to our findings, Mauser et al. (1994a) documented no mortalities of females during brood rearing in California, and survival of brooding females was high in Minnesota (94.3\%) and New Brunswick (97\%) (Kirby and Cowardin 1986, Petrie et al. 2000). Therefore, we believe Mallard recruitment in west-central Illinois was not limited by survival of broodrearing females.

\section{Recruitment}

We did not conduct breeding pair counts during our study; nonetheless, we perceived a decline in the breeding Mallard population as evidenced by lower capture rates of females during 2001-2003 compared to 1998-2000 (Table 2 ). Although speculative, the reduced number of breeding females on our study area may have resulted from poor recruitment in 1999 and 2000. Compared with the high capture rate achieved in 1999, apparent success in capturing resident females declined substantially during spring of 2001 through 2003. These lower capture rates reflected trends in our estimates 
of recruitment and the proportional population change. Interestingly, a similar trend was identified by the North American BBS during 1998-2003 for Mallards in Illinois (Sauer et al. 2007). Alternatively, returning females in subsequent years may have been reluctant to enter decoy traps, thereby lowering capture rates.

Fluctuations in resident Mallard populations in west-central Illinois during our study may have been indicative of Mallard population cycles in nontraditional breeding areas. Petrie (1999) and Simpson et al. (2005) suggested that wetlands of the Great Lakes Region were more stable than marshes of the Prairie Pothole Region, allowing for more consistent population maintenance and growth. However, Simpson et al. (2005) cautioned that constant duckling survival should not imply constant rates of recruitment. The apparent decline in recruitment documented during the 1999 and 2000 breeding seasons suggested that the Mallard breeding population in west-central Illinois suffered a notable decrease. The breeding population partially recovered due to better hen success in 2001-2002, but the projected 2004 spring population remained well below the 1998 and 1999 population levels.

Recruitment of female Mallards in westcentral Illinois was highly variable. Likewise, Mauser and Jarvis (1994) found a highly variable recruitment rate $(0.31-1.26)$ in northern California and suggested the Mallard population in their study was increasing based on an average recruitment rate of 0.83 . Similarly, Mallard recruitment in Ontario (0.79-0.99) was considered sufficient for population maintenance (Hoekman et al. 2006b). However, recruitment rates observed in North Dakota (0.27; Cowardin et al. 1985) and Iowa (0.49; Fleskes 1986) were not sufficient for population growth.

Assuming the annual survival rates of female Mallards (adult 0.520, yearling 0.556) estimated by Smith and Reynolds (1992:312) for Wisconsin and Illinois were representative of Mallards in west-central Illinois, a recruitment rate of 0.613 was required to maintain a stable population on our study area. Consequently, a $36.4 \%$ hen success rate and a duckling survival rate of 0.413 would have achieved this level of recruitment. The Mallard population in westcentral Illinois declined during our study when the 6-year pooled hen success rate of $28.3 \%$ was below the hypothesized level necessary for population maintenance. Several years of high nest success and recruitment may be needed for the Mallard population to recover following the years of poor recruitment we documented.

\section{CONCLUSIONS AND MANAGEMENT IMPLICATIONS}

Most parameter estimates associated with Mallard reproduction and recruitment in west-central Illinois appeared to be within ranges observed in studies on nesting Mallards throughout North America. Based on estimated recruitment rates, hen success was adequate in 1998 and 2002 for population growth but was too low in the other years to maintain the population. In all but one year, female survival during the breeding season was comparable to other populations of Mallards in secondary production areas.

Our data indicated that management practices designed to increase nest success, hen success, and duckling survival would likely increase Mallard populations in west-central Illinois. These same parameters were identified as driving the population growth rate in mid-continent Mallards (Hoekman et al. 2002), and duckling survival and nest success were important breeding season parameters for the Great Lakes Mallard population (Simpson et al. 2005, Coluccy et al. 2008, Davis 2008). Establishing or protecting unfragmented grasslands (>20 ha) in areas lacking forests should benefit Mallards in Illinois (Herkert et al. 1993); however, larger tracts (>300 ha) were required to enhance duck nest success in the northern prairies (Clark and Nudds 1991, Clark et al. 1991, Phillips et al. 2003). Similarly, Reynolds et al. (2001) concluded that upland perennial cover in $40 \%$ of the landscape was needed to achieve Mallard nest success rates necessary for stable populations in North Dakota. Others have questioned the efficiency of management practices designed to increase nest success in 
the Great Lakes states due to low breeding densities of Mallards and the fragmented nature of the landscape (Coluccy et al. 2008). Yet, Mallard populations in Illinois have increased in recent decades despite the lack of large contiguous areas of grasslands ( $>300 \mathrm{ha}$ ); thus, larger tracts of grassland may not be as important to recruitment of Mallards in Illinois. Agricultural policies that convert farmland to grasslands and native habitats, such as the U.S. Department of Agriculture's Conservation Reserve, Conservation Reserve Enhancement, and Wetland Reserve programs, should be instrumental in increasing populations of nesting waterfowl in Illinois.

Grassland managers in Illinois should delay mowing until August to avoid destruction of Mallard nests. Upland nesting habitats should include a mixture of native warm and cool season grasses and forbs, and avoid monotypic stands of vegetation (Swanson and Duebbert 1989). In the absence of fire, prairie grasslands succeed rapidly to woody and undesirable nonindigenous vegetation (Voorhees and Cassel 1980, Johnson and Temple 1990, Kadlec and Smith 1992, Herkert et al. 1993, Schwartz and Hermann 1997, Askins 2000). Therefore, grassland vegetation in Illinois should be maintained, if possible, with prescribed burns conducted between mid-October to mid-March at least every 3 to 5 years. Grassland manipulations should be staggered so residual nesting cover $\geq 60 \mathrm{~cm}$ tall is available in all years, and burns should be rotated between fall and early spring.

Although our estimates of brood and duckling survival in west-central Illinois were comparable to other Mallard production areas, the overall lack of emergent marshes with their associated escape cover and abundant aquatic invertebrates may have suppressed brood and duckling survival in west-central Illinois. In fact, Coluccy et al. (2008) identified duckling survival as one of the most important factors influencing the population growth rate of the Great Lakes Mallard population. Ideally, wetlands of all types and of reasonable quality, especially seasonal wetlands, should be restored or enhanced in close proximity to nesting areas (Swanson and Duebbert 1989, Afton and Paulus 1992, Rotella and Ratti 1992b, Simpson et al. 2005, Krapu et al. 2006, Raven et al. 2007, Coluccy et al. 2008, Davis 2008). A 50:50 interspersion of open water and emergent vegetation, such as broad-leaved cattail (Typha latifolia), American lotus (Nelumbo lutea), and softstem bulrush (Schoenoplectus tabernaemontani), is preferred in shallow basins to provide spacing for breeding pairs and courtship and high-quality brood habitat that offers escape cover and invertebrate forage for ducklings (Weller and Spatcher 1965, Courcelles and Bedard 1979, Mack and Flake 1980, Talent et al. 1982, Kaminski and Prince 1984, Belanger and Couture 1988, Swanson and Duebbert 1989, Kadlec and Smith 1992, Sedinger 1992, Stafford and Pearse 2007). Wetlands and lakes at MWRD were typical of older strip-mined lands in that they were generally stable, open-water bodies lacking emergent and submersed aquatic vegetation. Therefore, restoration and enhancement of emergent marshes and the aquatic invertebrates they support would likely provide conditions to enhance Mallard recruitment in west-central Illinois.

Further research is warranted to evaluate annual survival of females and ducklings in Illinois. Survival estimates of resident postbreeding females and post-fledging juveniles from banding and radiotelemetry investigations would provide better estimates of recruitment in Illinois. Indeed, nonbreeding survival was the most important parameter driving the population growth rate in other Great Lakes studies (Coluccy et al. 2008). Migratory patterns (including molt movements) of Illinois' resident Mallards are largely unknown, and information on the relationship between current hunting practices (e.g., spinning-winged decoys) and harvest in Illinois and other states is needed to better understand Mallard population dynamics. West-central Illinois contains many man-made lakes and ponds that often lack shallow-water foraging sites and escape cover for ducklings; therefore, investigations of the energetics of breeding Mallards and broods in this region would provide information to aid future management, restoration, and rehabilita- 
tion programs. Lastly, additional telemetry studies would provide insight into the effects of grassland establishment (filter strips and patch size), grassland management (burning, mowing, and haying), and current agricultural practices (conservation tillage and no-till) on nesting Mallards in Illinois.

\section{ACKNOWLEDGMENTS}

This study was supported through Federal Aid in Wildlife Restoration Project W-130-R with cooperation from the IDNR, INHS, and the U.S. Fish and Wildlife Service. The form, content, and data interpretation are the responsibility of the University of Illinois and the INHS. We thank J. Moore, T. Skuse, D. Prater, and staff at the Metropolitan Water Reclamation District of Greater Chicago and B. Douglass and J. Ball at the IDNR Banner Marsh State Fish and Wildlife Area for advice and assistance. The following INHS staff assisted with this project: P. White, B. Amdor, E. Whetsell, L. Anderson, R. Hillemeyer, J. Steckel, D. Strubing, B.

O'Neal, A. Bartlett, and K. Roat. Veterinary consultation for radio-transmitter attachment was provided by the Institutional Animal Care and Use Committee (IACUC) at the University of Illinois at Urbana-Champaign (UIUC), and R. Yetter, D.V.M., Havana, IL. The Illinois Department of Transportation, Division of Aeronautics, Springfield, IL, and P. Mankin, UIUC, Department of Forestry, Urbana, IL, provided aerial support for the project. Gamefarm Mallards used during decoy trapping were purchased from Whistling Wings, Inc., Hanover, IL. We thank L. Flake, L. Fredrickson, J. Levengood, and C. Warwick for their critical review of the manuscript. 


\section{LITERATURE CITED}

Afton, A.D., and S.L. Paulus. 1992. Incubation and brood care. Pages 62-108 in B.D.J. Batt, A.D. Afton, M.G. Anderson, C.D. Ankney, D.H. Johnson, J.A. Kadlec, and G.L. Krapu, eds. Ecology and management of breeding waterfowl. University of Minnesota Press, Minneapolis.

Alisauskas, R.T., and C.D. Ankney. 1992. The costs of egg laying and its relationship to nutrient reserves in waterfowl. Pages 30-61 in B.D.J. Batt, A.D.

Afton, M.G. Anderson, C.D. Ankney, D.H. Johnson, J.A. Kadlec, and G.L. Krapu, eds. Ecology and management of breeding waterfowl. University of Minnesota Press, Minneapolis.

Arnold, T.W., D.W. Howerter, J.H. Devries, B.L. Joynt, R.B. Emery, and M.G. Anderson. 2002. Continuous laying and clutch-size limitations in Mallards. Auk 119:261-266.

Arnold, T.W., M.D. Sorenson, and J.J. Rotella. 1993. Relative success of overwater and upland Mallard nests in southwestern Manitoba. J. Wildl. Manage. 57:578-581.

Artmann, M.J. 1999. Influence of upland cover on occupancy rates of nest structures by Mallards. M.S. thesis, University of Montana, Missoula.

Askins, R.A. 2000. Restoring North America's birds: lessons from landscape ecology. Yale University Press, New Haven, CT. 320 pp.

Ball, I.J., M.J. Artmann, and S.T. Hoekman. 2002. Does Mallard clutch size vary with landscape composition? Wilson Bull. 114:404-406.
Beauchamp, W.D., R.R. Koford, T.D. Nudds, R.G. Clark, and D.H. Johnson. 1996. Long-term declines in nest success of prairie ducks. J. Wildl. Manage. 60:247-257.

Belanger, L., and R. Couture. 1988. Use of man-made ponds by dabbling duck broods. J. Wildl. Manage. 52:718 723.

Bellrose, F.C. 1980. Ducks, geese, and swans of North America. 3rd ed. Stackpole Books, Harrisburg, PA. 504 pp.

Bergmann, P.J., L.D. Flake, and W.L. Tucker. 1994. Influence of brood rearing on female Mallard survival and effects of harness-type transmitters. J. of Field Ornith. 65:151-159.

Burnham, K.P., and D.R. Anderson. 2002. Model selection and multimodel inference: a practical information-theoretic approach. Second edition. SpringerVerlag, New York, NY. 488 pp.

Byers, S.M. and J.R. Cary. 1991. Discrimination of Mallard strains on the basis of morphology. J. Wildl. Manage. 55:580-586.

Carney, S.M. 1992. Species, age and sex identification of ducks using wing plumage. U.S. Department of Interior, Fish and Wildlife Service, Washington, D.C. $144 \mathrm{pp}$.

Chouinard, M.D., and T.W. Arnold. 2007. Survival and habitat use of Mallard (Anas platyrhynchos) broods in the San Joaquin Valley, California. Auk 124:1305-1316.

Clark, R.G., and T.D. Nudds. 1991. Habitat patch size and duck nesting success: the crucial experiments have not been performed. Wildl. Soc. Bull. 19:534543. 
Clark, R.G., T.D. Nudds, and R.O. Bailey. 1991. Populations and nesting success of upland-nesting ducks in relation to cover establishment. Canadian Wildl. Serv. Prog. Notes No. 193. 6 pp.

Clark, R.G., L.G. Sugden, R.K. Brace, and D.J. Nieman. 1988. The relationship between nesting chronology and vulnerability to hunting dabbling ducks. Wildfowl 39:137-144.

Coluccy, J.M., T. Yerkes, R. Simpson, J.W. Simpson, L. Armstrong, and J. Davis. 2008. Population dynamics of breeding Mallards in the Great Lakes states. J. Wildl. Manage. 72:1181-1187.

Coulter, M.W., and W.R. Miller. 1968. Nesting biology of Black Ducks and Mallards in northern New England. Vermont Fish and Game Department Bulletin 68-2. $74 \mathrm{pp}$.

Courcelles, R., and J. Bedard. 1979. Habitat selection by dabbling ducks in the Baie Noire Marsh, southwestern Quebec. Can. J. Zool. 57:2230-2238.

Cowardin, L.M., V. Carter, F.C. Golet, and E.T. LaRoe. 1979. Classification of wetlands and deepwater habitats of the United States. U.S. Dep. Inter., Fish and Wildl. Serv. FWS/OBS-79/31. $103 \mathrm{pp}$.

Cowardin, L.M., D.S. Gilmer, and C.W. Shaffer. 1985. Mallard recruitment in the agricultural environment of North Dakota. Wildl. Mono. No. 92. 37pp.

Cowardin, L.M., and D.H. Johnson. 1979. Mathematics and Mallard recruitment. J. Wildl. Manage. 43:18-35.

Cox, R.R., Jr., M.A. Hanson, C.C. Roy, N.H. Euliss, Jr., D.H. Johnson, and M.G. Butler. 1998. Mallard duckling growth and survival in relation to aquatic invertebrates. J. Wildl. Manage. 62:124-133.
Davis, J.B., R.M. Kaminski, and S.E. Stephens. 1998. Wood Duck eggshell membranes predict duckling numbers. Wildl. Soc. Bull. 26:299-301.

Davis, J.I. 2008. Mallard nesting ecology in the Great Lakes states. M.S. thesis, University of Montana, Missoula.

Devries, J.H., J.J. Citta, M.S. Lindberg, D.W. Howerter, and M.G. Anderson. 2003. Breeding season survival of Mallard females in the Prairie Pothole Region of Canada. J. Wildl. Manage. 67:551-563.

Dinsmore, S.J., G.C. White, and F.L. Knopf. 2002. Advanced techniques for modeling avian nest survival. Ecology 83:3476-3488.

Doty, H.A. 1975. Renesting and second broods of wild Mallards. Wils. Bull. $87: 115$.

Drever, M.C., A. Wins-Purdy, T.D. Nudds, and R.G. Clark. 2004. Decline of duck nest success revisited: relationships with predators and wetlands in dynamic prairie environments. Auk 121:497-508.

Droege, S., and J.R. Sauer. 1990. North American breeding bird survey annual summary, 1989. U.S. Fish and Wildlife Service Biological Report 90:1-22.

Duebbert, H.F. 1969. High nest density and hatching success of ducks on South Dakota CAP land. Trans. N. Am.Wildl. Nat. Res. Conf. 34:218228.

Dufour, K.W., C.D. Ankney, and P.J. Weatherhead. 1993. Condition and vulnerability to hunting among Mallards staging at Lake St. Clair, Ontario. J. Wildl. Manage. 57:209-215. 
Dwyer, C.P., and G.A. Baldassarre. 1993.

Survival and nest success of sympatric female Mallards, Anas platyrhynchos, and American Black Ducks, A. rubripes, breeding in a forested environment. Can. Field-Naturalist 107:213-216.

Dzubin, A., and J.B. Gollop. 1972. Aspects of Mallard breeding ecology in Canadian parkland and grassland. Pages 113-152 in Population ecology of migratory birds: a symposium. U.S. Dept. Inter. Wildlife Research Report No. 2.

Errington, P.L. 1934. Second broods in the Mallard duck. Auk 51:78-80.

Evrard, J.O. 2002. Duck production and harvest in St. Crois and Polk Counties, Wisconsin. Wisconsin Dept. of Nat. Res. Tech. Bull. No. 194. 38 pp.

Figley, W.K., and L.W. Van Druff. 1982. The ecology of urban Mallards. Wildl. Mono. No. 81. 40 pp.

Fleskes, J.P. 1986. Evaluation of waterfowl recruitment at Union Slough National Wildlife Refuge. M.S. thesis. Iowa State University, Ames.

Ford, E. R., C.C. Sanborn, and C.B. Coursen. 1934. Birds of the Chicago region. The Chicago Academy of Sciences 5:18-80.

Fredrickson, L.H., and T.S. Taylor. 1982. Management of seasonally flooded impoundments for wildlife. U.S. Fish and Wildlife Service, Resour. Pub. 148. Washington, DC. 29 pp.

Gatti, R.C. 1987. Duck production: the Wisconsin picture. Wisconsin Dept. Nat. Res. Research Management/Findings 1(February):1-4.
Gendron, M., and R.G. Clark. 2002. Survival of Gadwall and Mallard ducklings in south-central Saskatchewan. J. Wildl. Manage. 66:170-180.

Gloutney, M.L., R.G. Clark, A.D. Afton, and G.H. Huff. 1993. Timing of nest searches for upland nesting waterfowl. J. Wildl. Manage. 57:597-601.

Greenwood, R.J., R.G. Clark, and P.J. Weatherhead. 1986. Condition bias of huntershot Mallards (Anas platyrhynchos). Can. J. Zool. 64:599-601.

Greenwood, R.J., A.B. Sargeant, D.H. Johnson, L.M. Cowardin, and T.L. Shaffer. 1987. Mallard nest success and recruitment in Prairie Canada. Trans. N. Am. Wildl. and Nat. Res. Conf. 52:298-309.

Greenwood, R.J., A.B. Sargeant, D.H. Johnson, L.M. Cowardin, and T.L. Shaffer. 1995. Factors associated with duck nest success in the Prairie Pothole Region of Canada. Wildl. Mono. No. 128. $57 \mathrm{pp}$.

Gunnarsson, G., J. Elmberg, K. Sjoberg, H. Poysa, and P. Nummi. 2004. Why are there so many empty lakes? Food limits survival in Mallard ducklings. Can. J. Zool. 82:1698-1703.

Havera, S.P. 1999. Waterfowl of Illinois: status and management. Illinois Natural History Survey, Special Publication 21. $628 \mathrm{pp}$.

Herkert, J.R., R.E. Szafoni, V.M. Kleen, and J.E. Schwegman. 1993. Habitat establishment, enhancement and management for forest and grassland birds in Illinois. Illinois Department of Conservation, Division of Natural Heritage. Natural Heritage Tech. Pub. No. 1. 20 pp. 
Hernandez. F., D. Rollins, and R. Cantu. 1997. Evaluating evidence to identify ground-nest predators in west Texas. Wildl. Soc. Bull 25:826-831.

Higgins, K.F. 1977. Duck nesting in intensively farmed areas of North Dakota. J. Wildl. Manage. 41:232-242.

Hine, C.S., S.P. Havera, R.M. Whitton, and J.R. Serie. 1996. Fall and spring body weights and condition indices of ducks in Illinois. Trans. IL Acad. Sci. 89:197-213.

Hoekman, S.T., T.S. Gabor, R. Maher, H.R. Murkin, and L.M. Armstrong. 2004. Factors affecting survival of Mallard ducklings in southern Ontario. Condor 106:485-495.

Hoekman, S.T., T.S. Gabor, R. Maher, H.R. Murkin, and M.S. Lindberg. $2006 a$. Demographics of breeding female Mallards in southern Ontario, Canada. J. Wildl. Manage. 70:111-120.

Hoekman, S.T., T.S. Gabor, M.J. Petrie, R. Maher, H.R. Murkin, and M.S. Lindberg. 2006b. Population dynamics of Mallards breeding in agricultural environments of eastern Canada. J. Wildl. Manage. 70:121-128.

Hoekman, S.T., L.S. Mills, D.W. Howerter, J.H. Devries, and I.J. Ball. 2002. Sensitivity analyses of the life cycle of midcontinent Mallards. J. Wildl. Manage. 66:883-900.

Huseby, J., W.D. Svedarsky, and R.D. Crawford. 2001. Dabbling duck production from a wild rice farming landscape in northwest Minnesota. Wildl. Soc. Bull. 29:838-845.
Illinois Agricultural Statistics Service. 2004. Illinois agricultural statistics. 2004 annual summary, Bulletin 2004-1. Illinois Department of Agriculture and U.S. Department of Agriculture. Springfield, IL. 144 pp.

Illinois Department of Energy and Natural Resources. 1994. The changing Illinois environment: critical trends. Summary Report and Volumes 1-7 Technical Report. Illinois Department of Energy and Natural Resources, Springfield, IL, ILENR/RE-EA-94/05.

Johnson, D.H. 1979. Estimating nest success: the Mayfield method and an alternative. Auk 96:651-661.

Johnson, D.H., L.M. Cowardin, and D.W. Sparling. 1986. Evaluation of a Mallard productivity model. Pages 23-29 in J. Verner, M.L. Morrison, and C.J. Ralph, eds. Wildlife 2000: Modeling habitat relationships of terrestrial vertebrates. The University of Wisconsin Press, Madison.

Johnson, D.H., D.W. Sparling, and L.M. Cowardin. 1987. A model of the productivity of the Mallard duck. Ecol. Modeling 38:257-275.

Johnson, R.G., and S.A. Temple. 1990. Nest predation and brood parasitism of tallgrass prairie birds. J. Wildl. Manage. 54:106-111.

Kadlec, J.A, and L.M. Smith. 1992. Habitat management for breeding areas. Pages 590-610 in B.D.J. Batt, A.D. Afton, M.G. Anderson, C.D. Ankney, D.H. Johnson, J.A. Kadlec, and G.L. Krapu, eds. Ecology and management of breeding waterfowl. University of Minnesota Press, Minneapolis. 
Kaminski, R.M., and H.H. Prince. 1984. Dabbling duck-habitat associations during spring in Delta Marsh, Manitoba. J. Wildl. Manage. 48:37-50.

Kantrud, H.A. 1993. Duck nest success on Conservation Reserve Program land in the Prairie Pothole Region. J. Soil and Water Cons. 48:238-242.

Kaplan, E.L., and P. Meier. 1958. Nonparametric estimation from incomplete observations. J. Am. Stat. Assoc. 53:457-481.

Kennicott, R. 1855. Catalogue of the animals observed in Cook County, Illinois. [Birds.] Trans. IL State Agric. Soc. 1:580-589.

Kirby, R.E., and L.M. Cowardin. 1986. Spring and summer survival of female Mallards from north-central Minnesota. J. Wildl. Manage. 50:38-43.

Kleinbaum, D.G. 1996. Survival analysis: a self-learning text. Spring-Verlag New York, Inc. New York, NY. 324 pp.

Klett, A.T., H.F. Duebbert, C.A. Faanes, and K.F. Higgins. 1986. Techniques for studying nest success of ducks in upland habitats in the Prairie Pothole Region. U.S. Fish and Wildl. Serv. Res. Pub. No. 158. 24 pp.

Klett, A.T., T.L. Shaffer, and D.H. Johnson. 1988. Duck nest success in the Prairie Pothole Region. J. Wildl. Manage. 52:431-440.

Krapu, G.L., and H.A. Doty. 1979. Age-related aspects of Mallard reproduction. Wildfowl 30:35-39.

Krapu, G.L., D.H. Johnson, and C.W. Dane. 1979a. Age determination of Mallards. J. Wildl. Manage. 43:384-393.
Krapu, G.L., A.T. Klett, and D.G. Jorde. 1983. The effect of variable spring water conditions on Mallard reproduction. Auk 100:689-698.

Krapu, G.L., P.J. Pietz, D.A. Brandt, and R.R. Cox, Jr. 2000. Factors limiting Mallard brood survival in prairie pothole landscapes. J. Wildl. Manage. 64:553-561.

Krapu, G.L., P.J. Pietz, D.A. Brandt, and R.R. Cox, Jr. 2006. Mallard brood movements, wetland use, and duckling survival during and following a prairie drought. J. Wildl. Manage. 70:14361444.

Krapu, G.L., R.R. Reynolds, G.A. Sargeant, and R.W. Renner. 2004. Patterns of variation in clutch size in a guild of temperate-nesting dabbling ducks. Auk 121:695-706.

Krapu, G.L., L.G. Talent, and T. J. Dwyer. $1979 b$. Marsh nesting by Mallards. Wildl. Soc. Bull. 7:104-110.

Krementz, D.G., and G.W. Pendleton. 1991. Movements and survival of American Black Duck and Mallard broods on Chesapeake Bay. Proc. Annu. Conf. Southeast Assoc. Fish and Wildl. Agencies 45:156-166.

Krementz, D.G., D.B. Stotts, G.W. Pendleton, J.E. Hines, and V.D. Stotts. 1992. Comparative productivity of American Black Ducks and Mallards nesting on Chesapeake Bay islands. Can. J. Zool. 70:225-228.

Kruse, A.D., and B.S. Bowen. 1996. Effects of grazing and burning on densities and habitats of breeding ducks in North Dakota. J. Wildl. Manage. 60:233-246. 
LaGrange, T.G., J.L. Hansen, R.D. Andrews, A.W. Hancock, and J.M. Kienzler. 1995. Electric fence predator exclosure to enhance duck nesting: a longterm case study in Iowa. Wildl. Soc. Bull. 23:261-266.

Lee, F.B., R.L. Jessen, N.J. Ordal, R.I. Benson, J.P. Lindmeier, R.E. Farmes, and M.M. Nelson. 1964. Ducks and land use in Minnesota. Minnesota Dept. of Cons. Tech. Bull. No. 8. 140 pp.

Livezey, B.C. 1981. Duck nesting in retired croplands at Horicon National Wildlife Refuge, Wisconsin. J. Wildl. Manage. 45:27-37.

Lokemoen, J.T., and R.O. Woodward. 1992. Nesting waterfowl and waterbirds on natural islands in the Dakotas and Montana. Wildl. Soc. Bull. 20:163171.

Louis, W. 1999. Nesting ecology and use of restored wetlands by Mallards (Anas platyrhynchos) in southeastern Illinois. M.S. thesis, University of Illinois, Urbana-Champaign.

Mack, G. D., and L. D. Flake. 1980. Habitat relationships of waterfowl broods on South Dakota stock ponds. J. Wildl. Manage. 44:695-700.

Mauser, D.M., and R.L. Jarvis. 1991. Attaching radio transmitters to 1-day-old Mallard ducklings. J. Wildl. Manage. 55:488-491.

Mauser, D.M., and R.L. Jarvis. 1994. Mallard recruitment in northeastern California. J. Wildl. Manage. 58:565-570.

Mauser, D.M., R.L. Jarvis, and D.S. Gilmer. 1994a. Survival of radio-marked ducklings in northeastern California. J. Wildl. Manage. 58:82-87.
Mauser, D.M., R.L. Jarvis, and D.S. Gilmer. 1994b. Movements and habitat use of Mallard broods in northeastern California. J. Wildl. Manage. 58:88-94.

Maxson, J.J., and M.R. Riggs. 1996. Habitat use and nest success of overwater nesting ducks in west-central Minnesota. J. Wildl. Manage. 60:108-119.

Mayfield, H.F. 1961. Nesting success calcu lated from exposure. Wilson Bull. 73:255-261.

Mayfield, H.F. 1975. Suggestions for calculating nest success. Wilson Bull. 87:456-466.

McLandress, M.R., G.S. Yarris, A.E.H. Perkins, D.P. Connelly, and D.G. Raveling. 1996. Nesting biology of Mallards in California. J. Wildl. Manage. 60:94-107.

McPherson, R.J., T.W. Arnold, L.M. Armstrong, and C.J. Schwarz. 2003. Estimating the nest-success rate and the number of nests initiated by radiomarked Mallards. J. Wildl. Manage. 67:843-851.

Neckles, H.A., H.R. Murkin, and J.A. Cooper. 1990. Influences of seasonal flooding on macroinvertebrate abundance in wetland habitats. Freshwater Biology 23:311-322.

Neely, R.D., and C.G. Heister, compilers. 1987. The natural resources of Illinois: introduction and guide. Illinois Natural History Survey, Special Publication 6. 224 pp.

Nelson, E.W. 1876. Birds of northeastern Illinois. Bulletin of Essex Institute 8:90-155.

Nelson, J.S., and J.F. Wetzel. 2001. Summary report: long-term monitoring of nesting Mallards on Mississippi River islands. Wisconsin Dept. Nat. Res. Unpublished Report. 8 pp. 
Olsen, R.E., T. Yerkes, and J.W. Simpson. 2003. Occurrence of second broods in Mallards in the Midwest. Am. Midl. Nat. 150:302-307.

Orthmeyer, D.L., and I.J. Ball. 1990. Survival of Mallard broods on Benton Lake National Wildlife Refuge in northcentral Montana. J. Wildl. Manage. 54:62-66.

Paquette, G.A., J.H. Devries, R.B. Emery, D.W. Howerter, B.L. Joynt, and T.P. Sankowski. 1997. Effects of transmitters on reproduction and survival of wild Mallards. J. Wildl. Manage. 61:953-961.

Patterson, G.L. 1982. Hydrologic effects of storing liquified sewage sludge on strip-mined land, Fulton County, Illinois. U.S. Geological Survey, Water Resources Investigation 82-4047.

Pearse, A.T., and J.T. Ratti. 2004. Effects of predator removal on Mallard duckling survival. J. Wildl. Manage. 68:342350 .

Petrie, M. 1999. Mallards at the millennium: a status report on North America's most abundant, most adaptable, and most popular waterfowl species. Ducks Unlimited 63:56-64.

Petrie, M.J., R.D. Drobney, and D.T. Sears. 2000. Mallard and Black Duck breeding parameters in New Brunswick: a test of the reproductive rate hypothesis. J. Wildl. Manage. 64:832-838.

Phillips, M.L., W.R. Clark, M.A. Sovada, D.J. Horn, R.R. Koford, and R.J. Greenwood. 2003. Predator selection of prairie landscape features and its relation to duck nest success. J. Wildl. Manage. 67:104-114.
Pietz, P.J., D.A. Brandt, G.L. Krapu, and D.A. Buhl. 1995. Modified transmitter attachment method for adult ducks. J. Field Ornithol. 66:408-417.

Pietz, P.J., G.L. Krapu, R.J. Greenwood, and J.T. Lokemoen. 1993. Effects of harness transmitters on behavior and reproduction of wild Mallards. J. Wildl. Manage. 57:696-703.

Pollock, K.H., S.R. Winterstein, C.M. Bunck, and P.D. Curtis. 1989. Survival analysis in telemetry studies: the staggered entry design. J. Wildl. Manage. 53:7-15.

Raven, G.H., L.M. Armstrong, D.W. Howerter, and T.W. Arnold. 2007. Wetland selection by Mallard broods in Canada's Prairie Parklands. J. Wildl. Manage. 71(8):2527-2531.

Reinecke, K.J., and C.W. Shaiffer. 1988. A field test for differences in condition among trapped and shot Mallards. J. Wildl. Manage. 52:227-232.

Reynolds, R.E., T.L. Shaffer, R.W. Renner, W.E. Newton, and B.D. Batt. 2001. Impact of the Conservation Reserve Program on duck recruitment in the U.S. Prairie Pothole Region. J. Wildl. Manage. 65:765-780.

Ringelman, J.K. 1990. Decoy traps for ducks. Leaflet 13.2.10. in Waterfowl Management Handbook. U.S. Fish and Wild. Serv.

Ringelman, J.K., and M.R. Szymczak. 1985. A physiological condition index for wintering Mallards. J. Wildl. Manage. 49:564-568.

Riviere, R.L. 1999. Mallard use of wetland and agricultural habitats during the breeding season in California's San Joaquin Valley grasslands. M.S. thesis. University of Missouri, Columbia. 
Rotella, J.J., D.W. Howerter, T.P. Sankowski, and J.H. Devries. 1993. Nesting effort by wild Mallards with three types of radio transmitters. J. Wildl. Manage. 57:690-695.

Rotella, J.J., and J.T. Ratti. 1992a. Mallard brood survival and wetland habitat conditions in southwestern Manitoba. J. Wildl. Manage. 56:499-507.

Rotella, J.J., and J.T. Ratti. 1992b. Mallard brood movements and wetland selection in southwestern Manitoba. J. Wildl. Manage. 56:508-515.

Salyer, R.D., and M.A. Willms. 1997. Brood ecology of Mallards and Gadwalls nesting on islands in large reservoirs. J. Wildl. Manage. 61:808-815.

Samuel, M.D., and M.R. Fuller. 1996. Wildlife radiotelemtery. Pages 370-418 in T.A. Bookhout, ed. Research and management techniques for wildlife and habitats. Allen Press, Inc., Lawrence, $\mathrm{KS}$.

Sargeant, A.B. 1981. Road casualties of prairie nesting ducks. Wildl. Soc. Bull. 9:65-69.

Sargeant, A.B., S.H. Allen, and R.T. Eberhardt. 1984. Red fox predation on breeding ducks in midcontinent North America. Wildl. Mono. No 89. 41 pp.

Sargeant, A.B., M.A. Sovada, and R.J. Greenwood. 1998. Interpreting evidence of depredation of duck nests in the Prairie Pothole Region. U.S. Geological Survey, Northern Prairie Wildlife Research Center, Jamestown, ND and Ducks Unlimited, Inc., Memphis, TN. $72 \mathrm{pp}$.
Sauer, J.R., J.E. Hines, and J. Fallon. 2007. The North American breeding bird survey, results and analysis 19662006. Version 10.13.2007. USGS Patuxent Wildlife Research Center, Laurel, MD.

Schwartz, M.W., and S.M. Hermann. 1997. Midwestern fire management: prescribing a natural process in an unnatural landscape. Pages 213-233 in M.W. Schwartz, ed. Conservation in highly fragmented landscapes. Chapman and Hall, New York.

Sedinger, J.S. 1992. Ecology of prefledging waterfowl. Pages 109-127 in B.D.J. Batt, A.D. Afton, M.G. Anderson, C.D. Ankney, D.H. Johnson, J.A. Kadlec, and G.L. Krapu, eds. Ecology and management of breeding waterfowl. University of Minnesota Press, Minneapolis.

Shaffer, T.L., and W.E. Newton. 1995. Duck nest success in the Prairie Potholes. Pages 300-302 in E.T. LaRoe, G.S. Farris, C.E. Puckett, P.D. Doran, and M.J. Mac, eds. Our living resources report to the nation on the distribution, abundance, and health of U.S. plants, animals, and ecosystems. U.S. Dept. of the Interior, National Biological Service, Washington, DC.

Sharp, D.E., and J.T. Lokemoen. 1987. A decoy trap for breeding-season Mallards in North Dakota. J. Wild. Manage. 51:711-715.

Simpson, J.W., T.J. Yerkes, B.D. Smith, and T.D. Nudds. 2005. Mallard duckling survival in the Great Lakes region. Condor 107:898-909.

Smith, A.G. 1971. Ecological factors affecting waterfowl production in the Alberta parklands. U.S. Dept. Inter., Fish Wildl. Serv., Bur. Sport Fish Wildl. Res. Pub. No. 98. 49 pp. 
Smith, G.W., and R.E. Reynolds. 1992. Hunting and Mallard survival, 1979-88. J. Wildl. Manage. 56:306-316.

Smith, R.P. 1982. Animal tracks and signs of North America. Stackpole Books, Harrisburg, PA. 271 pp.

Sovada, M.A., R.J. Greenwood, and A.B. Sargeant. 1996. Interpreting evidence of depredation found at duck nests in the Prairie Pothole Region. Jamestown, North Dakota: Northern Prairie Wildlife Research Center Home http:// www.npwrc.usgs.gov/resource/tools/ eggguide/eggguide.htm (Version 16JUL97).

Stafford, J.D., L.D. Flake, and P.W. Mammenga. 2001. Evidence for double brooding by a Mallard, Anas platyrhynchos, in eastern South Dakota. Can. Field-Nat. 115:502-504.

Stafford, J.D., L.D. Flake, and P.W. Mammenga. 2002. Survival of Mallard broods and ducklings departing overwater nesting strictures in eastern South Dakota. Wildl. Soc. Bull. 30:327-336.

Stafford, J.D., and A.T. Pearse. 2007. Survival of radio-marked ducklings in eastern South Dakota. Wilson J. Ornith. 119:585-591.

Stoudt, J.H. 1971. Ecological factors affecting waterfowl production in the Saskatchewan parklands. U.S. Dept. Inter., Fish Wildl. Serv., Bur. Sport Fish Wildl. Res. Pub. No. 99. 58 pp.

Swanson, G.A., and H.F. Duebbert. 1989. Wetland habitats of waterfowl in the Prairie Pothole Region. Pages 228267 in A. Van Der Valk ed. Northern prairie wetlands. Iowa State Univ. Press, Ames.

Swanson, G.A., M.I. Meyer, and V.A. Adomaitis. 1985. Foods consumed by breeding Mallards on wetlands of south-central North Dakota. J. Wildl. Manage. 49:197-203.
Swanson, G.A., T.L. Shaffer, J.W. Wolf, and F.B. Lee. 1986. Renesting characteristics of captive Mallards on experimental ponds. J. Wildl. Manage. 50:32-38.

Talent, L.G., R.L. Jarvis, and G.L. Krapu. 1983. Survival of Mallard broods in south-central North Dakota. Condor 85:74-78.

Talent, L.G., G.L. Krapu, and R.L. Jarvis. 1982. Habitat use by Mallard broods in south-central North Dakota. J. Wildl. Manage. 46:629-635.

Titman, R.D. 1981. A time-activity budget for breeding Mallards (Anas platyrhynchos) in Manitoba. Can. Field-Nat. 95:266-271.

U.S. Fish and Wildlife Service. 2007a. Waterfowl population status, 2007. U.S. Department of the Interior, Washington, D.C. $61 \mathrm{pp}$.

U.S. Fish and Wildlife Service. 2007b. Migratory bird hunting activity and harvest during the 2005 and 2006 hunting seasons: Preliminary estimates. U.S. Department of the Interior, Washington, D.C. 62 pp.

Voorhees, L.D., and J.F. Cassel. 1980. Highway right-of-way: mowing versus succession as related to duck nesting. J. Wildl. Manage. 44:155-163.

Warner, R.E., and S.L. Etter. 1989. Hay cutting and the survival of Pheasants: a long-term perspective. J. Wildl. Manage. 53:455-461.

Weik, A.P., and R.A. Malecki. 1999. Survival of Mallard ducklings, broods, and hens in western New York. Northeast Wildl. 54:1-11.

Weller, M.W. 1956. A simple field candler for waterfowl eggs. J. Wildl. Manage. 20:111-113. 
Weller, M.W., and C. E. Spatcher. 1965. Role of habitat in the distribution and abundance of marsh birds. Agric. Home Econ. Exp. Stn. Spec. Rep. 43. 31 pp.

Wheeler, W.E., and J.R. March. 1979. Characteristics of scattered wetlands in relation to duck production in southeastern Wisconsin. Wisconsin Dept. of Nat. Res. Tech. Bull. No. 116. 61 pp.

White, G.C., and R.A. Garrott. 1990. Analysis of wildlife radio-tracking data. Academic Press, Inc., San Diego, CA. $372 \mathrm{pp}$.

Yerkes, T., and C. Bluhm. 1998. Return rates and reproductive output of captivereared female Mallards. J. Wildl. Manage. 62:192-198.

Yerkes, T., and T. LaFarge. 2002. Understanding Great Lakes Mallards. Birdscapes Fall:20.

Yetter, A.P. 1992. Population densities and use of palustrine wetlands by breeding waterfowl in northeastern Illinois. M.S. thesis, Southern Illinois University, Carbondale.

Zar, J.H. 1996. Biostatistical analysis. 3rd. ed. Prentice-Hall, Inc., Upper Saddle River, NJ. 662 pp.

Zicus, M.C., J. Fieberg, and D.P. Rave. $2003 a$. Does Mallard clutch size vary with landscape composition: a different view. Wilson Bull. 115:409-413.

Zicus, M.C., and D.P. Rave. 1998. Assessment of a Mallard model in Minnesota's prairie coteau. Minnesota Wildlife Report No. 12. Minnesota Dept. Nat. Res. 43 pp.

Zicus, M.C., D.P. Rave, and M.R. Riggs. 2003b. Mass loss from Mallard eggs incubated in nest structures. Wildl. Soc. Bull 31:270-278.
Zimmerling, J.R., J.R. Fisher, C.D. Ankney, and C.A. Debruyne. 2006. Mallard use of Hen Houses in eastern Ontario. Avian Conservation and EcologyEcologie et conservation des oiseaux 1:6. [on-line] URL: http//www.aceeco.org/vol1/iss2/art6/.

Zuwerink, D.A. 2001. Changes in the derivation of Mallard harvests from the northern U.S. and Canada, 1966-1998. M.S. thesis, The Ohio State University, Columbus. 
NOTES 

University of Illinois

Institute of Natural Resource Sustainability

William Shilts, Executive Director

Illinois Natural History Survey

Brian D. Anderson, Director

Forbes Natural History Building

1816 South Oak Street

Champaign, Illinois 61820

217-333-6880 